\title{
International Migrant Remittances in the Context of Economic and Social Sustainable Development. A Comparative Study of Romania-Bulgaria
}

\author{
Alina Petronela Haller ${ }^{1}$, Rodica Cristina Butnaru ${ }^{2}$ and Gina Ionela Butnaru ${ }^{3, *}$ \\ 1 Department of Economics, Romanian Academy Branch of Iaşi + ICES, Gh. Zane, Codrescu 2, \\ 700488 Iaşi, Romania; hallalinap@gmail.com \\ 2 Strategy Social and Environmental Responsibility Department, School of Management Sciences, \\ University of Quebec at Montreal, PO Box 8888, Downtown Branch Montreal, QC H3C 3P8, Canada; \\ reteaca.rodica_cristina@uqam.ca \\ 3 Department of Management, Marketing and Business Administration, \\ Alexandru Ioan Cuza University of Iaşi, Bulevardul Carol I 11, 700506 Iaşi, Romania \\ * Correspondence: gina.butnaru@uaic.ro; Tel.: +40-232-201-453
}

Received: 3 March 2018; Accepted: 4 April 2018; Published: 12 April 2018

\begin{abstract}
The economic stability is the main goal of every country's administration, contributing to the decrease of uncertainty, creating an attractive business environment, attracting foreign direct investment and contributing to economic growth, which increases the standard of living, reduces income inequalities, represents a sustainable development for the country and puts an end to the migration process. Migration flows lower the demographic resources of the states going through this process and consequently they compromise the possibility for future generations to support a sustainable economic growth. Migration is a process with an aggressive and alarming manifestation in Romania and Bulgaria, raising the problem of the future capacity of these countries to ensure long-term economic and social sustainability and requiring an analysis framework from a scientific perspective. The current study proposes a comparative study to identify the important determinants of international migration in the EU28 and analyses the impact of remittances on economic growth/stability and income inequality in Romania and Bulgaria-Central and Eastern Europe countries-for the period between 1990 and 2015. The main contribution of the present study consists in emphasising the common determinants of the two countries regarding the migration process and at the same time providing solutions to improve government policies to contribute to the economic and social sustainability. The authors employed a multiple regression model and the correlation analysis, and tested 8 hypotheses for Romania and Bulgaria. The results indicated that the main determinants of the migration process in Romania and Bulgaria are the inflation rate, the income inequality and household consumption expenditure. Furthermore, the results indicated that there is not a direct relationship between the remittances received/capita and GDP/capita growth rate in Romania and Bulgaria. In addition, there is a direct relationship (negative and with average intensity) between the remittances received/capita and price inflation rate in Romania but not in Bulgaria. In the case of Romania and Bulgaria, the results indicate that there is a direct relationship with a similar intensity between the remittances received/capita and the unemployment rate, the household final consumption and income inequality.
\end{abstract}

Keywords: migration; EU28; remittances; growth; income per capita; spending per capita; income inequality 


\section{Introduction}

Sometimes, migration is perceived as a threat to the labour market, to the security of incomes, to employment and to local culture. According to Giddens [1], people accept paying taxes to show solidarity with people like them, who share the same values and principles and who are not immigrants. The problem with migrants is more delicate. The migration flows affect the demography of the sender country and of the host country. The decrease in the numbers of an active population in a state means a decrease in the number of human resources, births, people who contribute to the state budget by paying taxes and fees, qualified workers which in the long term weakens the economic basis of a country and its capacity to support development. Migration has ambivalent effects for the countries of origin and for the host countries. In time, the countries of origin are the most affected, because the migrants intend to reach the developed countries which by migration solve many of their demographic problems. Any economy characterised by massive migration outflows tends to compensate the losses in human resources by exploiting the land and the underground and by energy-intensive production, raising questions regarding the possibility of future sustainable development. We start from the premise that there is a negative influence relation between the migration outflows from developing countries and their sustainability.

Migration is considered a wealth-generating phenomenon for the country of origin and the host country in the context of over 200 million people living in another country other than their country of origin [2]. In the paper Migration and Remittances. Recent Developments and Outlook, the causes of migration include different income and political and demographic factors. The same paper states that the global minimisation of the negative effects and the manner in which the positive effects are amplified represent the main aspects associated with migration [3]. Migration has both positive and negative effects. According to Rosenzweig [4], for example, the positive effects of migration consist, among others, in the increase of the price of qualified work on the emigrants' market of origin, an increase of the income by remittances and an increase of investments, especially in education. The negative effects are correlated with the demographic decrease, labour market unbalance, and according to Antman [5], with psychological effects on the families who stay in the country of origin. The effect of remittances is considerable for the emerging and less developed states. If remittances emphasise the inequalities in the sender country, emigration will stimulate emigration [6]. Emigration is a self-fed process. The migrants established on other territories will help other people to migrate, offering at the same time the example of success and of beneficial chances away from the country of origin, where the living conditions are unsatisfactory for the remaining population. In the case of emerging states (countries with high development potential like Brazil, Russia, India, China, Mexico, Turkey, Poland, Romania, Bulgaria and many others), in 2009 global remittances represented 1.9\% of GDP, and in the case of less developed states they represented $5.4 \%$ of GDP. The difficulties for these countries appear when migration takes the form of brain drain [2]. Sometimes, migration contributes to the demographic balance of the destination countries and to the economic balance of the countries of origin. According to Skeldon [7], the demographic balance is reflected in the composition of the population from the point of view of births, deaths and net migration (the difference between immigrants and emigrants). Births and immigration contribute to the population growth and deaths and emigration contribute to the population decline. According to the demographic balance, emigration determines the decrease in the number of individuals in a country, especially of the active ones. Remittances are money earned by immigrants in the host country, which go into circulation in the market of the country of origin. The volume of remittances is under-evaluated, because they do not always officially reach the immigrants' country of origin. If in the developed countries the foreigners represent cheap labour used in some sectors with the purpose of remaining competitive on the market, remittances represent important sources of income for the migrant sending countries [8].

Their impact is generally positive, with an effect of multiplication. Remittances directly and indirectly raise the national income, the rates of investments and consumption (a great part of remittances are used to purchase land and housing) and the demand. In addition, they stimulate 
the production and creation of jobs and implicitly the income of the families who do not receive remittances, they are introduced into the educational and health systems. However, they also manifest negative effects like an increase in income inequality, a decrease of the interest of those who receive them to be active in the labour market, the creation of dependence on these amounts because the beneficiaries of remittances lose their motivation to work, relying exclusively on the amounts sent regularly by the members of the family who are settled outside the country, inflation pressures because the remittances are money without coverage in domestic production. The retreat of the population from the labour market and the inflation pressures lead to an unbalance which on average and over the long term creates pressures on the economic safety of future generations and implicitly on sustainability. We must state that remittances are not totally reinvested in the formal economy. The distribution of incomes depends on the situation of the beneficiary families, if they are poor or rich [9]. The degree of wealth of a family benefitting from remittances dictates how they will be used. The poor families channel their remittances towards expenses for products of subsistence, while the rich families invest them especially in real estate, education and health.

Remittances are used to purchase real estate as a safe and long-term investment. This is the context in which migration is seen as a positive externality. Romanians and Bulgarians try by migration to ensure their material status. The remittances are directed towards the purchase of land and buildings, or constructions. Often, the decision to emigrate is directly proportional to the possibility to purchase a house. As the income in the country of origin is too low to reach such an objective, people choose to migrate. Many Romanians and Bulgarians send a part of their income earned abroad with the precise purpose of investing in real estate, with the intention to go back to their country of origin and stay there.

In the speciality literature regarding remittances, there are studies on: the relationship between remittances and the development of the financial sector [10], the effects of remittances on children's education and school attendance [11], the relationship between remittances and legislation [12], the net effects of migration and remittances on income distribution [13], the effect of remittances on the residents of an economy [14], the relationship between immigrants' behaviour and their motivation to migrate and their attitude towards remittances [15-17], the relationship between remittances and economic growth [18-20] and also GDP growth [21] the influence of remittances on fiscal sustainability in dependent economies [22] and on sustainable development [23].

This research has the purpose to contribute to a field less studied: investigation of the determining factors of the migration process, and impact of international migrants' remittances on the sustainable economic and social development of Romania and Bulgaria, countries geographically placed in Central and Eastern Europe. According to Daianu et al. [24], Romania and Bulgaria are among the countries with a relatively high dependence on remittances, offering security especially to poor and unemployed people, contributing to the increase of wealth and of national income, to import financing and to the decrease of current account deficit. In agreement with Haller $[25,26]$, we make the distinction between sustainable economic development and sustainable social development, that is, the economic one is synonymous to growth, representing an increase of macro-indicators. When growth (economic development) influences a society by the increase of wealth, we are speaking about sustainable social development. Not any economic progress is positively influencing the society, therefore it is necessary to make the distinction between the two concepts, one quantitative and the other qualitative.

The investigation of the determinants of the migration process was performed by using migration economic factors like unemployment rate, inflation rate, and level of expenses/capita to analyse the macroeconomic balance. The analysis of economic growth was performed by measuring the impact of remittances on the increase of GDP/capita and on the income inequality in Romania and Bulgaria. The Gini coefficient used explains the impact of sustainable social development. As we presented above, there are few papers explaining the impact of remittances on sustainability. The current study intends to contribute by its results to the literature in the field, analysing also the impact of remittances on sustainable economic and social development in Romania and Bulgaria, countries on which no 
such comparative studies have been performed. The theoretical model tested is obtained as a result of the review of speciality literature, including relevant studies from the field of migration.

\section{Literature Review}

\subsection{Conceptual Approach}

The topic of migration is neither new, nor little discussed, on the contrary. Migration is analysed from a multi- and transdisciplinary perspective: geographically, economically, sociologically, psychologically, anthropologically, also from the perspective of causalities, theories and effects (Table 1).

Table 1. Migration-perspectives of analysis.

\begin{tabular}{cll}
\hline \multirow{2}{*}{$\begin{array}{c}\text { Perspectives } \\
\text { of Analysis }\end{array}$} & \multicolumn{2}{c}{ Theories of Migration } \\
\hline & Deographical & Ravenstein [27], Rogers [28], Zelinsky [29], Wright [30], King [31] \\
\cline { 2 - 3 } & economic & $\begin{array}{l}\text { Piore [32], Hanson [33], Giddens [1], Kurekova [34], Collins et al. [35], } \\
\text { Galbraith [36] }\end{array}$ \\
\cline { 2 - 3 } $\begin{array}{c}\text { Multi-and } \\
\text { transdisciplinary }\end{array}$ & sociological & $\begin{array}{l}\text { Stark, Bloom [37], Gieseck [38], McDowell, De Haan [39], } \\
\text { Boswell [40,41], O'Reilly [42], Kerr, Kerr [43] }\end{array}$ \\
\cline { 2 - 3 } & psychological & $\begin{array}{l}\text { Binnie [44], Berry [45], Esses et al. [46], Gurieva, Kinunen [47], } \\
\text { Brown [48] }\end{array}$ \\
\cline { 2 - 3 } & anthropological & Colson [49], Fitzgerald [50], Horevitz [51], Salaza [52], Kempny [53] \\
\cline { 2 - 3 } $\begin{array}{c}\text { Causality, theories } \\
\text { and effects }\end{array}$ & theories & Solow [55], Kalinowska, Knapińska [56] Kurekova [34] \\
\cline { 2 - 3 } & effects & Borjas [57,58], Orefice [59], Giddens [1], Kerr, Kerr [43] \\
\cline { 2 - 3 } & myths & De Hein [60-62], Coyle [63] \\
\hline
\end{tabular}

The starting point in the theoretical analysis of migration is Solow model. Solow [55] considers that migrants contribute to an increase in the number of unqualified members of the population in the host country and to a decrease in incomes per capita, unlike Borjas [57,58], who explains the migration surplus as a an accumulation of benefits for the host country [59].

The migration theories made the object of many researches. Budnik [54] analyses from the standpoint of temporary migration (when the period of stay on another territory is up to a year), by analysis levels, the reasons for the decision to emigrate, the choice of destination, the markets, the utility and the mechanisms. Galbraith [36] associates the causality of migration with economic inequity. The population living illegally on the territory of a country forms a sub-class of second-hand residents, with no political representations and no civil rights. This sub-class is responsible for the worsening conditions on the labour market, the natives being affected by unemployment. Providing the migrants with civil rights results in bigger migration flows, as networks are formed and start functioning, while the entire phenomenon gets the nature of a political issue.

De Hein [60-62] analyses the myths of migration, reaching a series of conclusions: the period of the end of last century and the beginning of the present one is not characterised by massive migration waves; the cases of migration are not exclusively stories of poverty and misery, but, among other things, the manifestation of knowledge and the existence of networks; the relationship between migration and development is neither linear, nor directly proportional. Furthermore, the policies of development and trade liberalisation are not the most effective remedies against this phenomenon, as development stimulates and does not inhibit migration. Coyle [63] also refers to the myths of migration. She considers that migrants reduce welfare and weaken the health systems. However, the first-generation immigrants bring a net contribution to the state through the taxes they pay, which is 
higher than the value of medical care and of the benefits they get. There is a difference between the economic effects of old migration, compared to the ones of new migration. Coyle agrees that the expansion of migration needs an adaptation of infrastructure in the host country (more dwellings, more hospitals, more schools) and the migration waves are related to the income inequities in the countries of origin. The aggravation of poverty puts much pressure on migration, the destination being the rich countries.

According to the World Bank [3], migration brings advantages to the countries of origin if they are states with low incomes. The remittances represent for poor countries the main source of money for currency exchanges, the main possibility to reduce utter destitution, the main source of investments and capital accumulation. There are situations when migration becomes a mechanism for economic and demographic balance.

Studying migration in the EU, Kerr and Kerr [43] reached the conclusion that the migration flows are asymmetrical and heterogeneous: Sweden is preferred by refugees, Germany has a highly represented Turkish minority, while people of Moroccan origin prefer the Netherlands. The immigrants' participation rates to the labour market are lower than those of the natives, especially in the countries where the benefits offered are abundant. The immigrants with a high level of education come from European states (a third are from developing European countries) but their level of education is poorer than the locals'. From the standpoint of causality, the authors consider that the mobility is due to the differences between incomes, also the living conditions and the oppressive regimes in the countries of origin. The choice of destination depends on financial factors, on personal security, on the distance from the country of origin, on the existence of migration networks.

\subsection{Starting Point-Initial Migration Theories and Models}

Free circulation across wide territories enables the mobility of the people looking for conditions able to guarantee or improve their wealth. The theories of mobility are not recent. One of the most famous classical theories was formulated by Zelinsky in 1971 [29]. The theory of territorial mobility considers migration a synonym of circulation, seen as a change of residence for a determined or undetermined period of time. The migration process is divided into five stages, starting with the Middle Ages and up to a future left at the discretion of our imagination or of reality, as events occur in time. The five stages go from a relatively low mobility, specific to the pre-modern period, to a relatively high one, specific to the modern period.

Migration is an intensely theorised topic, developed in micro- and macro-approaches (theories) [64], also mixt approaches, combinations of the first categories.

The micro-theories emphasise aspects of the system of values such as migrants' wishes, expectations and resources, analysing the factors influencing individually the decision to migrate. This group of theories includes the expectancy-value model and the stress-threshold model, and the cost-benefit model. The expectancy-value model, developed by Crawford [65], is based on the hypothesis stating that behaviour depends on expectations and values. It is a cognitive model, according to which migrants make decisions according to economic factors and education [66]. The stress-threshold model, developed by Wolpert [67], describes the rational migrant's behaviour before making the decision but not necessarily after that. According to the cost-benefit model, any decision generates positive effects (benefits) higher than the costs [68]. The migrant potential compares the costs-the available financial resources and the invested psychological resources to reach their purpose, with the benefits obtained-financial gains higher than those earned in their country of origin, in addition to personal security. The micro-theories explain how the macro- and the mezzo- factors are reflected in the individual decision to migrate.

The macro theories (pioneering gravity model, push and pull model) are focused on economic, demographic, political aspects and on characteristics specific to some regions and countries; for instance, legislation or global changes. The pioneering gravity model- or Ravenstein's law (1885) [27]—considers that migration has economic causes—-well-paid jobs and that the number 
of migrants diminishes with the increase of the distance from the country of origin [68]. Push and pull model, formulated by Lee in 1966 [64], considers that migration depends on factors specific to the place of origin, which push people to leave and on factors that pull individuals towards destinations with higher potential [56]. The push factors are economic (high unemployment rate, low level of payment, small income per capita). The pull factors are correlated with the regulations regarding migration and with the situation of the labour market in the host country.

The macro theories provide the best understanding of the factors promoting the voluntary migration phenomenon (the result of the personal decision to emigrate, based on several causes analysed by macro-theories) and the best explanation for involuntary migration [40,41].

The combination of micro and macro approaches formed the so-called mixed theories, of which the most relevant is the cost-usage theory, developed by Bogue. This theory combines specific elements of the push and pull model with elements of the cost-benefit model, by analysing the advantages and disadvantages offered by the countries of origin and of destination $[69,70]$.

The mezzo theories analyse the person-community relations, which, in their turn, influence the decision to leave the place of origin to settle down elsewhere. These theories actually fill the gaps left by the other two approaches. The mezzo theories also explain why voluntary migration is a long-term process and why some regions are more susceptible to the phenomenon, regardless of their position of migrant senders or migrant receivers.

The micro, macro and mezzo theories combine, forming mixt theories with mutual components.

The micro, macro, mezzo and mixt theories are divided into two other categories, one explaining the causes of migration (the neo-classical theory, the new economics of migration theory, the dual labour market theory, the world systems theory), and one explaining the resistance of the phenomenon in time (the network theory of migration, the migration systems theory, the cumulative causation theory).

The neo-classical theory considers that migration is the result of the differences of income among markets and countries, that is, it is the result of the heterogeneity of the labour market [34]. The new economics of migration theory starts from the neo-classical theory but it moves the decision of migration from the individual to the small community, that is, the decision to leave one's country of origin is not taken by each person apart but by their family $[37,38]$. Dual labour market theory correlates migration with structural changes, an important part being played by the demand. Developed by Piore in 1979 [32], this theory refers to the duality of the occupational structure and of the economic organisation in the developed states, where the capital-intensive branches provide good, safe and well-paid jobs, while the labour-intensive branches provide small wages, the capital being underused [70]. The world systems theory, developed by Collins et al. [35], considers migration the result of structural changes on the world markets induced by globalisation, by the increasing interdependence among countries and by the appearance of new forms of production.

The network theory of migration analyses the factors maintaining migration in time and in space, such as the existence of communities with a similar culture in the host country (networks). The people's behaviour is not determined only by their own culture, by individual attitudes and by demographic features. An important role is played by social relations, stimulating or constraining the behaviour of the people involved [71]. According to the migration systems theory, migration influences the social, cultural, economic and institutional conditions in the host countries, and in the countries of origin [34]. Cumulative causation theory, initially developed by Myrdal [72], considers migration a self-generated and self-fed process, due to the existence of networks and of a migration culture. In a vicious circle, migration is presented as a divergent and never a convergent process [60-62].

Based on the analysis of these migration theories, we proposed in Table 2 a theoretical model of migration on types of migration, dimensions and indicators. 
Table 2. Theoretical model of migration.

\begin{tabular}{|c|c|c|}
\hline \multicolumn{3}{|c|}{ Theories of Migration } \\
\hline Theories/Concept & Dimension & Indicators \\
\hline \multirow{4}{*}{ Macro $[60-62,73,74]$} & economic characteristics & $\begin{array}{l}\text { - well-paid jobs; } \\
\text { - high unemployment rate; } \\
\text { - low level of salaries; } \\
\text { - low income per capita. }\end{array}$ \\
\hline & demographic characteristics & $\begin{array}{l}\text { - demographic crisis; } \\
\text { - existence of migration networks; } \\
\text { - change of social structure. }\end{array}$ \\
\hline & political characteristics & $\begin{array}{l}\text { - political instability; } \\
\text { - political crises. }\end{array}$ \\
\hline & $\begin{array}{l}\text { characteristics specific to some } \\
\text { regions/countries }\end{array}$ & - legislation/regulations regarding migration. \\
\hline \multirow{4}{*}{ Micro $[65,67]$} & aspects of the system of values & $\begin{array}{l}\text { - wishes; } \\
\text { - expectations; } \\
\text { - migrants' resources; } \\
\text { - decision to migrate. }\end{array}$ \\
\hline & expectancy-value model & $\begin{array}{l}\text { - expectations; } \\
\text { - values. }\end{array}$ \\
\hline & stress-threshold model & $\begin{array}{l}\text { - the reason of migration in making decisions } \\
\text { before/after migration; }\end{array}$ \\
\hline & cost-benefit model & $\begin{array}{l}\text { - benefits (higher income than in the country of origin, } \\
\text { personal safety) }\end{array}$ \\
\hline Mezzo [64] & $\begin{array}{l}\text { person-community } \\
\text { relationship }\end{array}$ & - decision to leave the place of origin; \\
\hline \multicolumn{3}{|c|}{ Theories Explaining the Causes of Migration } \\
\hline Theories/Concept & Dimension & Indicators \\
\hline Neoclassical [34] & heterogeneity of labour market & - difference of income among markets and countries \\
\hline $\begin{array}{l}\text { The new economics } \\
\text { of migration }[37,38]\end{array}$ & decision aspects & - the decision to emigrate is made by the family; \\
\hline $\begin{array}{l}\text { Dual labour } \\
\text { market [32] }\end{array}$ & structural changes & $\begin{array}{l}\text { - demand; } \\
\text { - offer: better, safer and well-paid jobs-in } \\
\text { capital-intensive branches vs work-intensive jobs and } \\
\text { low salaries-in branches where the capital is } \\
\text { under-used. }\end{array}$ \\
\hline World Systems [35] & structural changes & - new forms of production. \\
\hline \multicolumn{3}{|c|}{ Theories Explaining the Resistance of the Phenomenon in Time } \\
\hline Theories/Concept & Dimension & Indicators \\
\hline $\begin{array}{l}\text { The network of } \\
\text { migration }[50,54]\end{array}$ & cultural & $\begin{array}{l}\text { - analyses the factors maintaining migration in time and } \\
\text { space }\end{array}$ \\
\hline $\begin{array}{c}\text { Migration } \\
\text { Systems }[1,32,34]\end{array}$ & $\begin{array}{l}\text { aspects in the host countries } \\
\text { and in the countries of origin }\end{array}$ & $\begin{array}{l}\text { - social aspects; } \\
\text { - cultural aspects; } \\
\text { - economic aspects; } \\
\text { - institutional aspects. }\end{array}$ \\
\hline $\begin{array}{l}\text { Cumulative } \\
\text { causation }[60-62,72]\end{array}$ & $\begin{array}{l}\text { migration as a } \\
\text { divergent process }\end{array}$ & $\begin{array}{l}\text { - number of community networks; } \\
\text { - migration culture. }\end{array}$ \\
\hline
\end{tabular}

The literature presents various theories emphasizing several variables which explain the level and the causes of the migratory process. Based on the assumption that the macro theories provide the best understanding of the factors promoting the voluntary migration phenomenon and the best explanation for involuntary migration $[40,41]$, the authors of this study decided to emphasis the economic characteristics. 
The economic stability is the main goal of every country administration and it is measured by the degree of achievement of their economic goals, including the increase of individual welfare mirrored in measures such as economic growth (GDP/capita growth rate), low employment, price stability, or growing consumption [75].

The promotion of economic stability contributes to the decrease of uncertainty, creates an attractive business environment, attracts foreign direct investment, contributing to economic growth, which increases the standard of living, reduces income inequalities, representing a sustainable development for the country and stops among others the migration process.

Remittances remain one of the primary sources of financing for economic growth in dependent economies.

As we can see, the literature does not present comparative studies on Romania and Bulgaria regarding the impact of remittances on economic growth and income inequality and on the evolution of the migratory process within EU28. The authors propose in this comparative study to identify the important determinants of the international migration in the EU28 and analyse the impact of remittances on economic growth/stability and income inequality in Romania and Bulgaria for the period 1990-2015.

This study will enable the authors to identify the common elements of the two countries regarding the migration process and at the same time will be able to provide solutions to improve government policies in reducing inequalities in society.

To examine and highlight the main causes of the migration process and to illustrate the main economic impacts of remittances in Romania and Bulgaria within the EU28, in Figure 1 we suggest the research model to be tested.

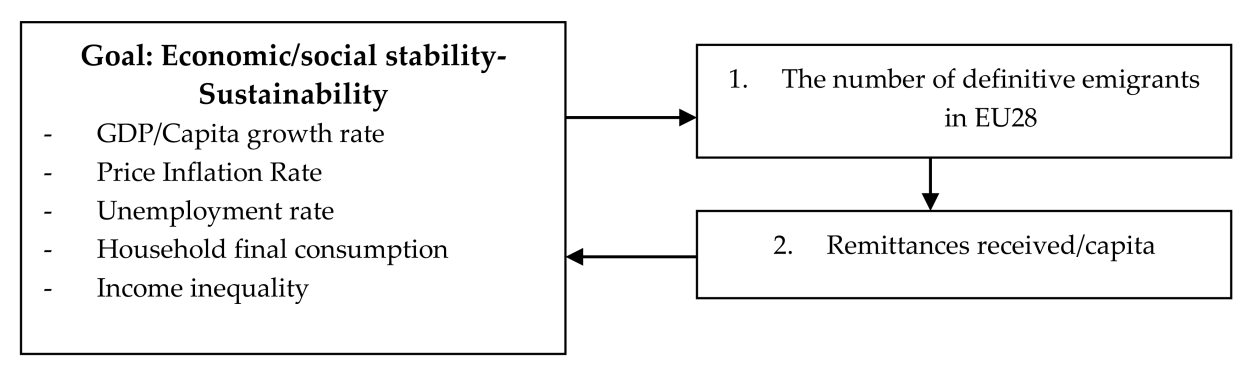

Figure 1. Research model. Source: made by authors.

\subsection{Analysis of Remittances in the Case of Romania and Bulgaria}

Lubambu [76] highlights the multiple role of remittances: for social insurance, being destined for consumption expenses, contributing thus to the decrease of severe poverty; of investment, especially in the medical and educational sector, for purchasing goods, albeit less sustainable ones in the long term.

In the case of Romania, remittances increased until 2008, then they slightly decreased until 2009, peak year of financial crisis. Between 2009 and 2012, remittances slightly increased compared to 2009, without reaching the level of 2008. After 2012, remittances had a relatively constant trend, with a slight decline in 2015. Starting with 2000, the volume of remittances increased, Romania being among the main beneficiaries of remittances in the world. In 2008, remittances represented 3.3\% of Romanian GDP (the fourth place in the world). However, their volume is difficult to estimate, because, according to Andrén and Roman [77], only $40 \%$ are sent officially sent into the country. The same authors show that between 2001 and 2003, the value of remittances was 2 billion dollars per year, higher than the direct foreign investment and in 2009 they reached 9.4 billion dollars. For 2012, remittances represented 2.2\% of Romanian GDP. Analysing the migration process in the case of Romania, Hărău [78] characterises the remittances as financial transfers compensating for the phenomenon of 'brain-drain' and the losses of human capital by migration outflows. The remittances increase the income of the country from external sources with effects on the standard of living of the beneficiaries, also on the local development 
by consumption and investments, however without a consensus regarding their contribution to the economic growth and creation of jobs. De Sousa and Duval [79] analyse the relationship between the geographical distance and remittances in the case of Romania for the period between 2005-2009. The conclusion of the study shows that the remittances grow proportionally with the geographical distance, however there is a descending tendency specific to a small group of countries according to the size of the country, the status of the financial and labour market. Silaşi and Simina [80] show that, after 2002, remittances supported the economic development of Romania. The remittance flows became higher than the direct foreign investments, with a role of compensating measures helping the beneficiaries to protect themselves in conditions of economic regression without acting as a capital source for the economic development. Consequently, Romania benefits from remittances only on short term and if it desires to maintain the current development tendency, it will need to import labour in the future.

In the case of Bulgaria, remittances represent a positive aspect of migration. In general, the positive effects of remittances are felt ever the short term. In the case of Bulgaria, they also have negative effects on the labour market, demographic structure, motivation to work, which manifested mostly on average and long term. After 2004, the volume of remittances increased considerably in the case of Bulgaria. In 2004, remittances represented 4.2\% of GDP and in 2006 they were 5.4\% of GDP [6]. In 2008 and 2009, years of financial crisis, the volume of remittances considerably decreased in Bulgaria and until 2012 their volume remained relatively constant. In 2013 remittances strongly increased, and subsequently their volume slightly decreased until 2015, when, after a slight decline, they started to increase again. According to Markova [81], the Bulgarians benefitting from remittances used them to cover basic needs and to purchase goods for long-term use, especially buildings and land, raising the standard of living and the economic growth by consumption and investments. Mintchev and Boshnakov [82] consider that $4-5 \%$ of the GDP of remittances do not make the economy depend on them, however it is enough to cover a substantial percentage of the commercial deficit with a positive impact on economic growth and macro-stability. In 2013, remittances represented 2.7\% of GDP. They are on an ascending tendency, even if migration is on a descending tendency, which means that migrants send more money to their country of origin. The volume of remittances increased proportionally with the degradation of the economic situation in the countries of origin. The decrease of the currency power of acquisition, the inflation boosts, the small income and increase of inequality in the country of origin determine the migrants to send more money to their families to help them. In addition, the improvement of the migrants' situation in the host country, especially their opportunity to find better paid jobs as they adapt (they learn the language and the customs of the host community, they increase their social circle) determines the growth of emigrants' income from which they send more money to their families at home. When the migrants legally settle in the host country, the volume of remittances decreases.

Mansoor and Quillin [83] quantify the remittances sent by Bulgarians and Romanians as $80 \%$ and $62 \%$ of their income, respectively, considering them a factor contributing to poverty decrease, of savings and investments, however also contributing to a decrease of the competitiveness of exports and of motivation to work.

Migration does not affect only the sustainable development of Romania and Bulgaria. Migration flows are specific to all former communist states of Central and Eastern Europe. The system change increased the number of opportunities for the Central and Eastern European population to look for better living conditions in the developed states, especially in Europe. The case of Romania and Bulgaria is special due to the high flows of emigrants which intensified after the 1990's, especially in 2007, when the adherence of the two countries to the EU brought the hope of a better life for the inhabitants of these states, however not in their countries but on the territory of developed European states, where the access became free. In 2009, year of crisis peak, remittances increased as a result of the worsening of the economic situation in Romania and Bulgaria. The intensification of migration outflows in the last years shows a tendency of life degradation in Romania and Bulgaria, also in the rest of the Central and Eastern European territory, even if the macroeconomic indicators do not entirely 
reflect it. GDP growth or decline does not mean anything as long as it is not analysed in relation with other indicators and these analyses certify that the Central and Eastern European states do not manage to decrease the development gaps. In their case, sustainability will become in time an acute problem if the tendency to leave the national territory continues. As long as the migration outflows maintain or even increase, the human resource will decrease without being replaced by immigration, because the Central and Eastern European countries are traditionally sending emigrants, without a conversely interest in immigrants.

\section{Perspectives of Migration of Romanians and Bulgarians inside EU28-Romanian Migrant Profile versus Bulgarian Migrant Profile}

Romania and Bulgaria have many points in common and one of them is that after 1989 both countries ceased to be communist states. Romanian and Bulgarian government started to be open to the international mobility of the labour force.

According to UN reports [84-86], the migration profile was made based on the country of origin and the period of reference. This profile was synthesised in Appendix A-Table A1 and Figure 2 presents the migration flow in the countries of the EU28, comparing Romania and Bulgaria.

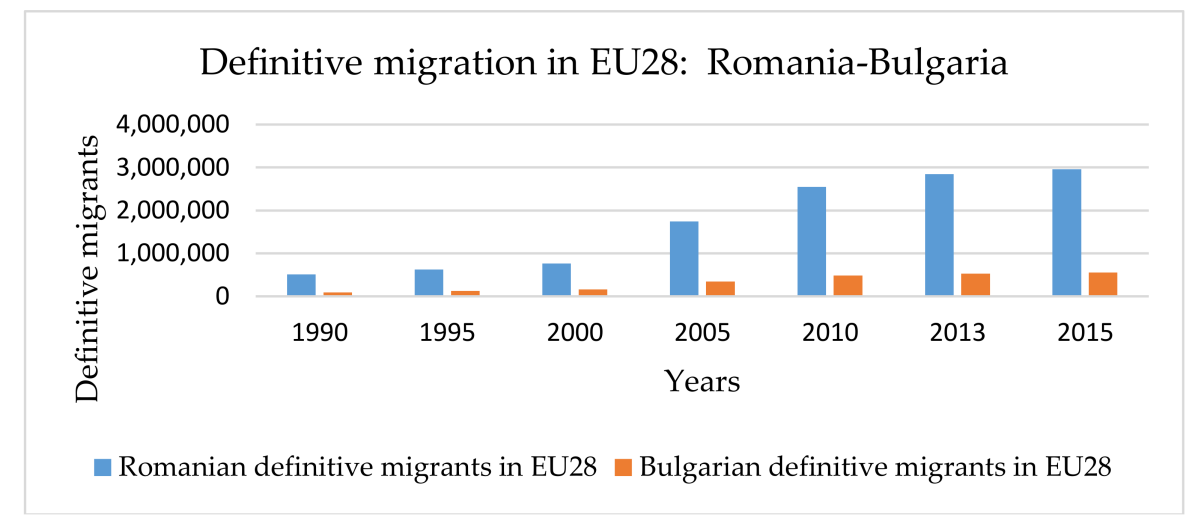

Figure 2. Definitive migrants in EU28: Romania and Bulgaria in 1990-2015. Source: [85].

An analysis of the data offered by UN accessible for the period between 1990-2013 enables us to present a picture of the migration phenomenon in Romania and Bulgaria. According to the data included in Appendix A, UN [84-86] shows a decrease in the number of emigrants in the case of Romania by $8 \%$ in 2013 compared to 1990 . The number of women who emigrated is higher than the number of men. If in 1990 352,000 women emigrated from Romania, in 2013 their number increased to 561,000 . These data reflect the psychological and mental profile of the population. Women are more inclined to work than men, which can be seen on the market. The number of working women is higher than the number of working men and the number of unemployed women is lower than the number of unemployed men. More people from the urban environment left the country than from the rural environment. The prevalence of emigrants originating from the rural environment is determined by the degree of education. The urban population adapts easier to the external environment due to their professional and linguistic knowledge, higher than in the case of the rural population. The analysis on periods of time shows that migration increased by $5.15 \%$ between $1985-1990$, by $-2.18 \%$ between 1995-2000, by $-1.79 \%$ between $2005-2010$ and by $-2.19 \%$ between $2010-2015$, considering the evolution of the number of emigrants in time. The long-term estimations performed by UN reflect a decrease in the number of emigrants. In 2050, the migration phenomenon will decrease in Romania by $6.53 \%$. In $1990,38.23 \%$ of the emigrant population went to Hungary and $34.84 \%$ chose Germany, according to the UN data. In 2015, the first destination was Italy with $34.54 \%$ of the total immigrant population, followed by Spain with $22.25 \%$ and Germany with $19.96 \%$. The emigrant population increased from 507,752 in 1990 to 2,957,726 in 2015. The population of Romania in 2015 
was 19.82 million. Consequently, $67 \%$ of the migrant population was distributed among 5 destinations. The main destinations of the Romanian emigrants were in 2013 Italy, Spain, Germany, Hungary and USA, according to the data provided by UN.

In the case of Bulgaria, the number of emigrants lowered by $22 \%$ in the same period. The number of women is higher than the number of men and growing. If in 1990 there were 12,300 more women than men who emigrated from Bulgaria, in 2013 there were 20,300. Most of the migrants are fit for work. The emigrants from the urban environment are much more than those from the rural environment. The estimates for the period between 2010-2015 showed a tendency of improvement of the phenomenon and the analysis until 2050 confirms the UN estimates. The number of Bulgarian emigrants is estimated to 5,077,000 in 2050, compared to 6,827,000 in 2020. According to the UN, the main destinations of the Bulgarian migrants were in 2013 Turkey, Romania, Spain, USA, Germany and UK. In 1990, 29.31\% of the Bulgarian emigrant population chose Germany as their first destination and in the same year $27.70 \%$ of the emigrant population went to Romania instead. The emigrant population increased from 92,389 people in 1990 to 555,197 in 2015, from a population of 7178 million. In $2015,23.40 \%$ of Bulgarian emigrant population went to Spain and $18.95 \%$ chose Germany as their destination.

As we can see, immediately after the fall of the Communist regime in both countries, the emigrant population chose their first destination based on geographic proximity and commodity (accessibility, advantages, etc.). The World Bank, as compared to the UN, offers data for 2015, when Italy, Spain and Germany were the most attractive destinations for Romanian and Bulgarian emigrants. The real GDP growth in 2015 for Germany by 1.7\%, for Spain by 3.2\% and for Italy by $0.8 \%$ and the average growth for EU28 in 2015 by $2.2 \%$ show that both Romanians and Bulgarians chose as destination countries the developed countries within EU28 [2].

One of the destinations preferred by Romanian and Bulgarian emigrants is UK, country which decided to exit the EU and where the emigrants' future, an important economic link, is questionable. Numerically, the Romanian emigrants overtake the Bulgarians. 7500 Romanians and 5350 Bulgarians entered officially the UK territory in 2001, the Bulgarians' emigration being gradual [87]. The flows of emigrants from A2 countries (Romania and Bulgaria) towards UK increased after 2004, especially towards London and the regions of East and South-East of England. After the adherence of the two countries to the EU, approximately 22,000 Romanians and 14,000 Bulgarians entered annually the territory of UK, especially London and the regions of South-East [88]. Approximately $90 \%$ of Romanian and Bulgarian emigrants who lived in the UK in 2007 were between 16 and 64 years old and they worked in constructions, real estate, commerce, hotels, and restaurants [86], especially in small and medium private companies [89]. According to Glennie and Pennington [88], the emigrants from the two countries are young and qualified. In the case of Romanians, $82 \%$ of the emigrants are 20-65 years old and 69\% are 20-39 years old, 52\% are men and $48 \%$ are women. In the case of Bulgarian emigrants, $44 \%$ are under 24 years old and $81 \%$ are under 34 years old. $60 \%$ of the Romanian and Bulgarian emigrants obtain relatively quickly the certification of their qualification, $18 \%$ having higher qualification in their country of origin. According to Glennie and Pennington [88], 82\% of the Romanians prove a good knowledge of English.

Analysing the remittances for Romania and Bulgaria, the situation is as follows:

However, we noticed that after 2000 and 2007, the volume of remittances has increased surprisingly for both countries. During 2000-2004, the increase of remittances was significant in the case of Romania. It was only after 2004 that the volume of remittances reached an ascending trend in the case of Bulgaria, lower than in Romania. The graph shows two inflexion points for both countries. One is characterising the adherence to the EU which offered the possibility of people's free circulation on the EU territory and the other shows the years of peak crisis which acutely influenced the Romanian and Bulgarian economy and society, respectively. A more detailed analysis of the evolution of Romania and Bulgaria remittances based on Figure 3 was performed in Section 2.2 of the paper. 


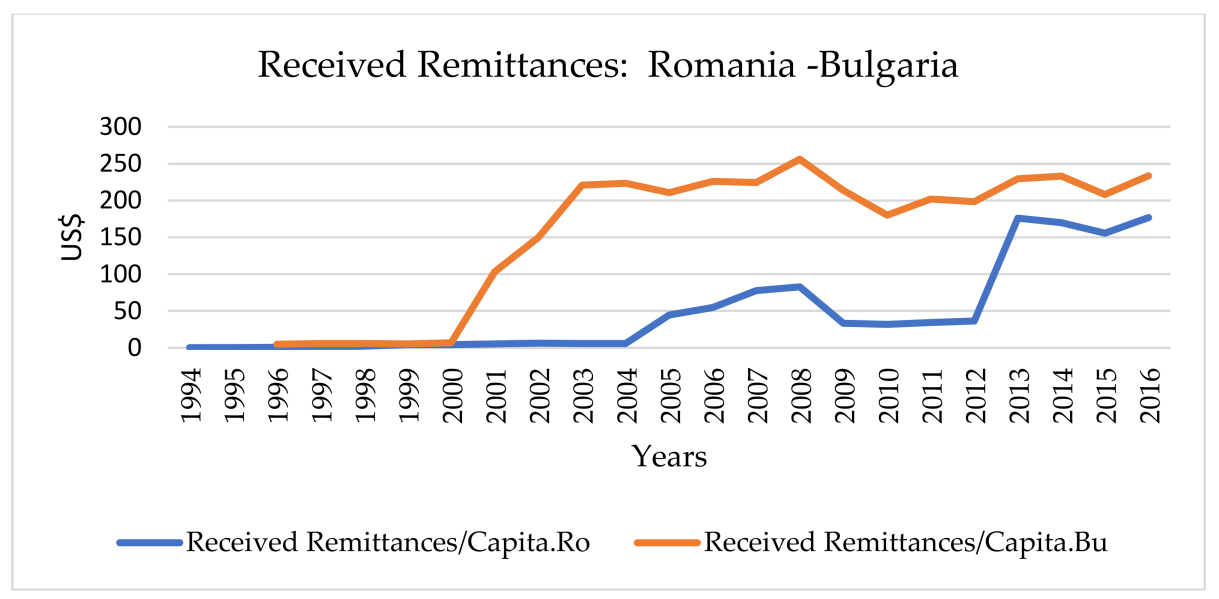

Figure 3. Received remittances per capita in Romania and Bulgaria in 1994-2016 (US dollars). Source: [2].

The income of the Romanian citizens is higher than the income of Bulgarian citizens since 2005 until now (Figure 4).

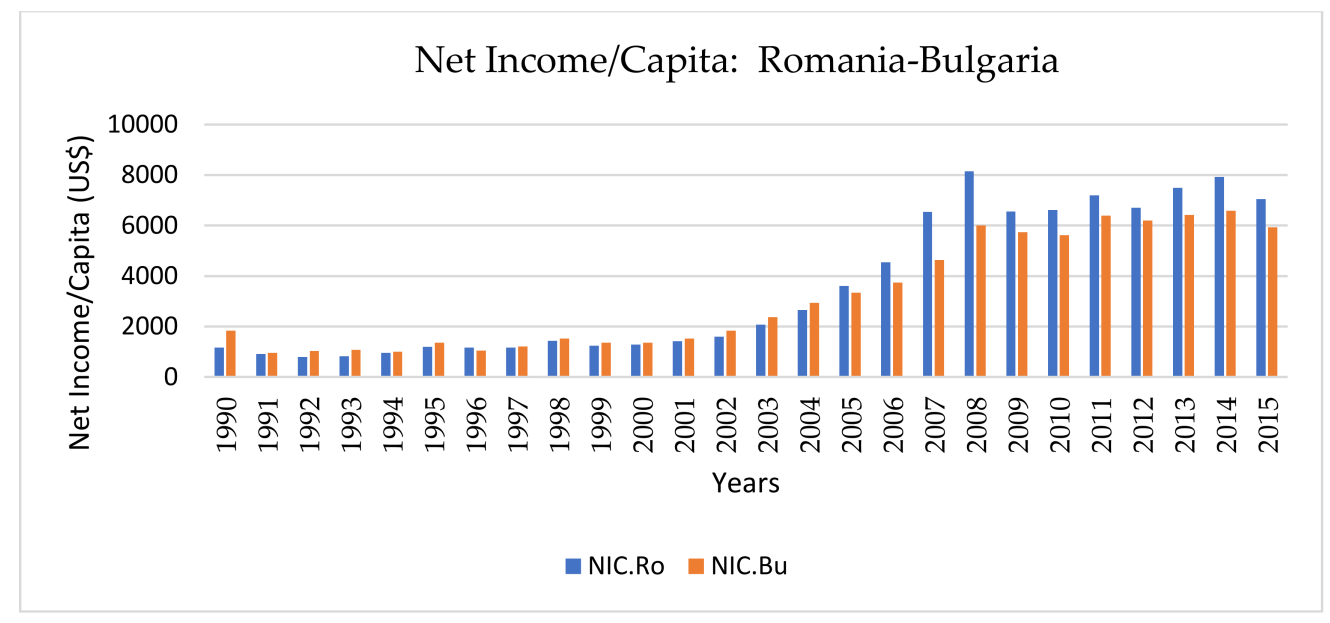

Figure 4. Net income per capita in Romania and Bulgaria in 1990-2015 (US dollars). Source: [2].

\section{Materials and Methods}

\subsection{Data}

In order to accomplish this comparative study of Romanians and Bulgarians within the EU28, the authors will use several databases such as: the annual databases for 1990-2015 presented by UN [84-86] and processed data presented by Eurostat [87] and the World Bank [2,3,86].

The purpose of this study is to:

1. define the determinants of the international migration in Romania and Bulgaria (see Table 3).

2. analyse the impact of remittances on economic growth and income inequality in Romania and Bulgaria (see Table 4). 
Table 3. Determinants of international migration.

\begin{tabular}{|c|c|c|}
\hline Theories/Dimensions & Dependent Variables Name (Code) & Independent Variables Name (Code) \\
\hline $\begin{array}{l}\text { Macro }[60-62,73,88] \\
\text { Economic } \\
\text { characteristics-push } \\
\text { factors-measuring } \\
\text { international migration }\end{array}$ & The number of definitive emigrants & $\begin{array}{l}\text { - The level of expenses/capita } \\
\text { - Unemployment rate } \\
\text { - GDP/capita } \\
\text { - Inflation Rate (CPI) } \\
\text { - Income inequality }\end{array}$ \\
\hline
\end{tabular}

Table 4. The impact of remittances.

\begin{tabular}{cll}
\hline \multicolumn{1}{c}{ Theories/Perspective } & Independent Variable Name & Dependent Variables Name \\
\hline & & - The level of expenses/capita \\
The impact of remittance: & & - Unemployment rate \\
economic and sociological & Remittances received/capita & - GDP/capita \\
{$[19,20,24,76,83,88-90]$.} & & - Inflation Rate (CPI) \\
& & - Income inequality \\
\hline
\end{tabular}

In Tables 3 and 4 we present the variables considered in the study of the determinants of the international migration:

1. GDP/capita growth rate. $\mathrm{Ro}(\mathrm{Bu})$ - GDP per capita growth (annual \%) represents annual percentage growth rate of GDP per capita based on constant local currency. Aggregates are based on constant 2010 U.S. dollars. GDP per capita is gross domestic product divided by midyear population. GDP at purchaser's prices is the sum of gross value added by all resident producers in the economy plus any product taxes and minus any subsidies not included in the value of the products. It is calculated without making deductions for depreciation of manufactured assets or for depletion and degradation of natural resources [91].

2. Price inflation rate $\mathrm{Ro}(\mathrm{Bu})$-Inflation Rate (CPI, annual variation in \%). World Bank presents the inflation as measured by the consumer price index, which reflects the annual percentage change in the cost to the average consumer of acquiring a basket of goods and services that may be fixed or changed at specified intervals, such as yearly. Laspeyre's formula is generally used [92].

3. Unemployment rate $\mathrm{Ro}(\mathrm{Bu})$ - Unemployment rate $(\%)$ represents unemployed workers, who are those who are currently not working but are willing and able to work for pay, currently available to work and have actively searched for work [93].

4. Household final consumption expenditure-Household Consumption Expenditure Ro(Bu) (current US\$). World Bank defines the household final consumption expenditure as formerly private consumption - the market value of all goods and services, including durable products, purchased by households. It excludes purchases of dwellings but includes imputed rent for owner-occupied dwellings. It also includes payments and fees to governments to obtain permits and licenses [94].

5. GINI.Ro(Bu)-Income inequality-Regarding the income inequality level, the authors considered the GINI coefficient presented in the GINI index, a World Bank estimate [95].

6. Total.Migrants.Ro(Bu) - The number of definitive emigrants-we considered the number of the migrants in the EU28 - Net migration is the net total of migrants during the period, that is the total number of immigrants less the annual number of emigrants, including both citizens and noncitizens [96].

7. Remittances received/capita $\mathrm{Ro}(\mathrm{Bu})$ - Personal remittances received (current US\$), we considered the definition provided by World Bank-Personal remittances comprise personal transfers and compensation of employees. Personal transfers consist of all current transfers in cash or in kind made or received by resident households to or from non-resident households. Personal transfers thus include all current transfers between resident and non-resident individuals. Compensation of employees refers to the income of border, seasonal, and other short-term workers who are employed in an economy where they are not resident and of residents employed by non-resident entities. Data are the sum of two items defined 
in the sixth edition of the IMF's Balance of Payments Manual: personal transfers and compensation of employees. Data are in current U.S. dollars [97].

In order to clarify the determinants of the international migration in Romania and Bulgaria, our research hypotheses take into consideration the economic characteristics-the push factors measuring the international migration from a macro theory perspective-and emphasize the influence of these variables in the case of Romania and Bulgaria. Consequently, we formulated the following hypotheses:

Hypotheses 1 (H1). The inflation and unemployment rate explain the number of definitive migrants in EU28 from Romania and Bulgaria.

Hypotheses 2 (H2). The unemployment rate and income inequality (Gini index) explain the number of definitive migrants in EU28 from Romania and Bulgaria.

Hypotheses 3 (H3). The household consumption expenditure and GDP growth rate/capita explain the number of definitive migrants in EU28 from Romania and Bulgaria.

In order to analyse the impact of remittances on economic stability and income inequality in Romania and Bulgaria, our research hypotheses take into consideration the economic characteristics measuring the economic stability such as: GDP/capita growth rate, price inflation rate, unemployment rate, household final consumption, income inequality, emphasizing the influence of these variables in the case of Romania and Bulgaria.

Consequently, we formulated the following hypotheses:

Hypotheses 4 (H4). There is a direct relationship between the remittances received/capita and GDP/capita growth rate.

Hypotheses 5 (H5). There is a direct relationship between the remittances received/capita and price inflation rate.

Hypotheses 6 (H6). There is a direct relationship between the remittances received/capita and unemployment rate.

Hypotheses 7 (H7). There is a direct relationship between the remittances received/capita and household final consumption.

Hypotheses 8 (H8). There is a direct relationship between the remittances received/capita and Gini Index (income inequality).

\subsection{Methodology-Regression Model with SPSS}

In order to define the determinants of the international migration and empirically investigate the impact of remittances on economic growth and income inequality in Romania and Bulgaria, the authors employed the multiple regression model and Pearson correlation analysis. Regression models are constructed to explain (or predict) the variance of a phenomenon (dependent variable) using a combination of explanatory factors (minimum two independent variables) [98].

The mathematical form of multiple regression model is represented as follows:

$$
\mathrm{Y}_{\mathrm{i}}:\left(\mathrm{b}_{0}+\mathrm{b}_{1} \mathrm{X}_{1}+\mathrm{b}_{2} \mathrm{X}_{2}+\ldots+\mathrm{b}_{\mathrm{n}} \mathrm{X}_{\mathrm{n}}\right)+\varepsilon_{\mathrm{i}}
$$

where:

$\mathrm{y}_{\mathrm{i}}=$ dependent variable (to be explained)

$\mathrm{x}_{\mathrm{i}}=$ independent variables (explanatory) 
$\mathrm{b}_{0}=\mathrm{a}$ constant which corresponds to the value of the dependent variable when all the independent variables are equal to zero.

$b_{n}=$ beta coefficient is a standardized form which corresponds to each independent variable and represents its relative contribution in the model.

$\varepsilon_{\mathrm{i}}=$ represents the residual-the difference between the observed value of the dependent variable and the predicted value.

Meticulously associated with the evaluation of the model, the multiple correlation index R2 represents the percentage of variance explained by the model (the combination of the independent variables).

The design of a regression model should relate on the choice of independent variables and the choice of the regression method. In our case we used the backward elimination method. We used the backward elimination criterion- the probability of $\mathrm{F}$ to remove $\geq 0.10$.

In this case, the initial model includes all the variables, as for forced regression and then the variable with the smallest contribution to the model will be removed if the variation of the R2 is not significant. This variable is eliminated from the model. The procedure will be repeated until all the conserved variables contribute significantly to the improvement of the R2.

This method simplifies the regression model and conserves only the variables contributing significantly.

To be able to apply the multiple regression model, the following most important premises should be observed: weak exogeneity, linear character, homostedasticity, independence, absence of multicollinearity, and so forth. Multicollinearity can be measured by calculated variance inflation factors (VIFs).VIF values higher than 10 indicate that multicollinearity may be a problem. Ideally would be to obtain a VIF value of 1 [98].

The null hypothesis (H0) is that there is no linear relationship between the combination of the independent variables $\left(\mathrm{X}_{1}, \mathrm{X}_{2}, \mathrm{X}_{3} \ldots \mathrm{X}_{\mathrm{n}}\right)$ and the dependent variable $(\mathrm{Y})$.

The research hypothesis (H1) is the opposite, that is, the combination of the independent variables is significantly associated with the dependent variable.

The first step is to evaluate the quality of the regression model-analysis of variance. The ANOVA test enables us to determine whether we reject the null hypothesis (H0) or not.

We verify if the model explains significantly more variability than a model without predictor (VI). Then, it is a question of ensuring that all the variables introduced contribute to significantly improve the variability explained by the final model. We analyse the null hypothesis that there is no relationship between the dependent variable and the independent variables by interpreting the results of the ANOVA test. We analyse the relevance of the model and we perform the F value test using the SPSS software. The value of $\mathrm{F}$ is significant at $p<0.001$. In this case, we must reject the null hypothesis and conclude that there is a statistically significant relationship between the dependent variable and the independent variables. On the other side, if the value of $\mathrm{F}$ were not accompanied by a significant $p$ value, the interpretation would stop here.

Subsequently, we examine the contribution of each block of variables. The "R2" value indicates the proportion of the variability of the dependent variable (y) explained by the regression model. The adjusted $\mathrm{R} 2$ value is an estimate of the robustness of the model.

In order to analyse the impact of remittances on economic stability and income inequality in Romania and Bulgaria, the authors employed the correlation analyses, by which we intended to determine the possible relationship between two variables, the intensity of the relationship and the direction of influence of a variable on the other. The correlation analysis is a bivariate statistical analysis consisting of the observation of an ensemble of units distributed according to the values of two variables, $\mathrm{X} 1$ and $\mathrm{X} 2$ [98]. The bivariate statistical analysis has the objective to identify the influence of a variable on another variable, of the direction and intensity of the connection between the two variables. 


\section{Results}

\subsection{Model of Migration-The Determinants of the International Migration in Romania and Bulgaria}

As mentioned in the methodology, we employed the multiple regression model-backward elimination method. As we previously mentioned, this analysis considers the period between 1990 and 2015 (26 years). Before presenting the results for Romania and Bulgaria, Table 5 shows a descriptive statistic of the independent variables considered to explain the number of definitive migrants of these two countries in the EU28 (dependent variable).

Table 5. Descriptive statistics—-the determinants of the international migration for Romania and Bulgaria.

\begin{tabular}{lccccc}
\hline & N & Minimum & Maximum & Mean & Std. Deviation \\
\hline GDP.Growth.Rate/Capita.Ro & 26 & -12.1584 & 10.2815 & 2.121745 & 5.8663212 \\
GDP.Growth.Rate/Capita.Bu & 26 & -7.5341 & 8.4700 & 2.155468 & 4.8229686 \\
Price inflation rate Ro & 26 & -0.59 & 256.10 & 54.0850 & 72.49390 \\
Price inflation rate Bu & 26 & -1.42 & 1061.20 & 75.0991 & 212.83490 \\
Unemployment rate Ro & 26 & 3.40 & 11.00 & 7.2923 & 1.63730 \\
Unemployment rate Bu & 26 & 2.90 & 18.10 & 11.5769 & 3.74682 \\
HouseholdConsumption & 26 & $1.58 \times 10^{10}$ & $1.32 \times 10^{11}$ & $6.1305 \times 10^{10}$ & $4.26385 \times 10^{10}$ \\
Expenditure Ro & & & & & $1.8819 \times 10^{10}$ \\
Household Consumption & 26 & $5.92 \times 10^{9}$ & $3.58 \times 10^{10}$ & $1.18250 \times 10^{10}$ \\
Expenditure Bu & 26 & 0.68 & 0.80 & 0.7383 & 0.04784 \\
GINI.Ro & 26 & 0.70 & 0.79 & 0.7373 & 0.03520 \\
GINI.Bu & & & & & \\
\hline
\end{tabular}

The GDP growth rate/capita mean is similar for the two countries considered in our study $(2.12 \%$ for Romania and 2.15\% for Bulgaria). The price inflation rate is higher in Bulgaria, which can be explained by the fact that in its case, there was a hyperinflation in 1991 and 1997; the inflation rate was $333.5 \%$ and $1061.20 \%$, respectively. In the case of Romania, the maximum value of price inflation was $256.10 \%$ in 1993 . The unemployment rate is higher in Bulgaria and the highest value (18.10\%) was in 2000. At that time, the unemployment rate in Romania was $7.6 \%$. The income inequality average score is similar for these two countries (0.8 in Romania and 0.79 in Bulgaria) but very high compared to the average of 0.3 for EU28 countries.

Table 6 presents the correlations between the studied variables and their Pearson correlation test. Correlation is significant at the 0.05 level (2-tailed) marked with ${ }^{*}$ ) in the table and the correlation is significant at 0.01 level (2-tailed), marked with $\left(^{* *}\right)$ in the table. If the correlation between two of these variables is significant, there would be a significant risk of multicollinearity. We want to avoid this situation. We can see that there is a very high and significant correlation between the variables GDP/capita growth rate, price inflation rate and unemployment rate for Romania but not correlated in the case of Bulgaria. We can see that GDP/capita growth is not correlated with Household Consumption Expenditure and GINI index (income inequality) for any of the two countries. 
Table 6. Correlation matrix-Independent Variables—Romania-Bulgaria.

\begin{tabular}{|c|c|c|c|c|c|c|}
\hline Variables & & $\begin{array}{l}\text { GDP.Growth.Rate/ } \\
\text { Capita. Ro(Bu) }\end{array}$ & $\begin{array}{c}\text { Price } \\
\text { Inflation } \\
\text { Rate } \operatorname{Ro}(\mathrm{Bu})\end{array}$ & $\begin{array}{l}\text { Unemployment } \\
\text { Rate Ro(Bu) }\end{array}$ & $\begin{array}{l}\text { Household } \\
\text { Consumption } \\
\text { Expenditure } \\
\text { Ro(Bu) }\end{array}$ & $\begin{array}{c}\text { GINI } \\
\operatorname{Ro}(\mathrm{Bu})\end{array}$ \\
\hline \multirow{2}{*}{ GDP.Growth.Rate/Capita.Ro } & Pearson Correl. & 1 & $-0.572 * *$ & $0.499 * *$ & 0.308 & 0.315 \\
\hline & Sig. (2-tailed) & & 0.002 & 0.010 & 0.126 & 0.117 \\
\hline \multirow{2}{*}{ GDP.Growth.Rate/Capita.Bu } & Pearson Correl & 1 & -0.265 & 0.288 & 0.214 & 0.354 \\
\hline & Sig. (2-tailed) & & 0.190 & 0.154 & 0.293 & 0.076 \\
\hline \multirow{2}{*}{ Price inflation rate $\mathrm{Bu}$} & Pearson Correl & -0.265 & 1 & 0.070 & -0.339 & -0.355 \\
\hline & Sig. (2-tailed) & 0.190 & & 0.734 & 0.090 & 0.075 \\
\hline \multirow{2}{*}{ Unemployment rate Ro } & Pearson Correl & $0.499 * *$ & -0.056 & 1 & -0.169 & -0.181 \\
\hline & Sig. (2-tailed) & 0.010 & 0.787 & & 0.410 & 0.376 \\
\hline \multirow{2}{*}{ Unemployment rate $\mathrm{Bu}$} & Pearson Correl & 0.288 & 0.070 & 1 & $-0.406^{*}$ & -0.256 \\
\hline & Sig. (2-tailed) & 0.154 & 0.734 & & 0.040 & 0.208 \\
\hline \multirow{2}{*}{ GINI. Ro } & Pearson Correl & 0.315 & $-0.742 * *$ & -0.181 & $0.971^{* *}$ & 1 \\
\hline & Sig. (2-tailed) & 0.117 & 0.000 & 0.376 & 0.000 & \\
\hline \multirow{2}{*}{ GINI.Bu } & Pearson Correl & 0.354 & -0.355 & -0.256 & $0.960 * *$ & 1 \\
\hline & Sig. (2-tailed) & 0.076 & 0.075 & 0.208 & 0.000 & \\
\hline
\end{tabular}

Data analysis shows that the variable price inflation rate in Romania is significant correlated with the variable GDP/capita, household consumption expenditure and GINI index. In the case of Bulgaria, the same variable is not correlated with the other variables. This situation can be explained in the case of Bulgaria with the hyperinflation episode mentioned above. If we isolate these 2 values, the correlation is following the same trend as in the case of Romania.

Hypotheses 1 (H1). The inflation and unemployment rate explain the number of definitive migrants in EU28 from Romania and Bulgaria.

Hypotheses 1.0. (H1.0.). The inflation and unemployment rate cannot explain the number of definitive migrants in EU28 from Romania and Bulgaria.

In Table 7, we can see that according to the F value obtained for the two models, the null hypothesis can be rejected in the case of Romania. Indeed, the values of 11.525 and 21.487 are significant at $p<0.001$, which indicates that we have less than $0.1 \%$ chances of being wrong in stating that the models contribute better to predict the number of definitive migrants in EU28.

Table 7. Assessing the Quality of the Regression Model.

\begin{tabular}{|c|c|c|c|c|c|}
\hline Case & Model & Sum of Squares & Sum of Squares & $\mathbf{F}$ & Anova Sig. \\
\hline \multirow{4}{*}{ Ro } & \multirow{4}{*}{1} & Regression & $1.012 \times 10^{13}$ & \multirow{3}{*}{11.525} & \multirow{3}{*}{$0.000^{\mathrm{a}}$} \\
\hline & & Residual & $1.010 \times 10^{13}$ & & \\
\hline & & Total & $2.022 \times 10^{13}$ & & \\
\hline & & Regression & $9.549 \times 10^{12}$ & \multirow{3}{*}{21.487} & \multirow{3}{*}{$0.000^{b}$} \\
\hline \multirow[t]{3}{*}{ Ro } & \multirow[t]{3}{*}{2} & Residual & $1.067 \times 10^{13}$ & & \\
\hline & & Total & $2.022 \times 10^{13}$ & & \\
\hline & & Regression & $1.222 \times 10^{11}$ & \multirow{3}{*}{2.386} & \multirow{3}{*}{$0.114^{\mathrm{a}}$} \\
\hline \multirow[t]{3}{*}{$\mathrm{Bu}$} & \multirow[t]{3}{*}{1} & Residual & $5.892 \times 10^{11}$ & & \\
\hline & & Total & $7.115 \times 10^{11}$ & & \\
\hline & & Regression & $8.133 \times 10^{10}$ & \multirow{3}{*}{3.098} & \multirow{3}{*}{$0.091^{b}$} \\
\hline \multirow[t]{2}{*}{$\mathrm{Bu}$} & \multirow[t]{2}{*}{2} & Residual & $6.301 \times 10^{11}$ & & \\
\hline & & Total & $7.115 \times 10^{11}$ & & \\
\hline
\end{tabular}

a Predictors: (Constant), Unemployment rate $\mathrm{Ro} / \mathrm{Bu}$ Price inflation rate $\mathrm{Ro} / \mathrm{Bu}$; ${ }^{\mathrm{b}}$ Predictors: (Constant), Price inflation rate Ro/Bu; Dependent Variable: Total.Migrants.Ro/Bu. 
For the case of Bulgaria, according to the $\mathrm{F}$ value obtained, the two models were not accompanied by a significant $(p<0.001) \mathrm{p}$ value $(p=0.114$ and 0.091$)$. We analyse the relevance of the model and we conclude that the null hypothesis cannot be rejected.

We employed the multiple regression model—backward elimination method. In this case, the initial model includes all the variables considered (model 1), such as price inflation rate and unemployment rate and model 2 is considering only one variable- the price inflation rate (we consider the backward elimination criterion- the probability of $\mathrm{F}$ to remove $\geq 0.10$. We can see in Table 8 that the unemployment rate is the variable with an insignificant contribution to the model and it was removed from the final model (model 2). The beta coefficient for this particular variable is not statistically significant with a value of -0.168 (i.e., the $t$-value is not significant with a value of $0.266 \geq 0.10$ ), the variable does not significantly predict the outcome. The variable price inflation rate presents a beta value of -0.697 and indicates that by each 1 -unit increase in the predictor variable, the outcome variable will decrease by 0.697 units.

Table 8. Testing the effects of unemployment rate and price inflation rate Ro on the total definitive migrants in EU28 in the case of Romania.

\begin{tabular}{|c|c|c|c|c|c|c|c|c|}
\hline Model & R Square & $\begin{array}{l}\text { Adjusted } \\
\text { R Square }\end{array}$ & $\begin{array}{c}\text { F } \\
\text { Change }\end{array}$ & $\begin{array}{l}\text { Sig. F } \\
\text { Change }\end{array}$ & $\begin{array}{l}\text { Standardised } \\
\text { Coefficients } \\
\text { Beta }\end{array}$ & $t$ & Sig & $\begin{array}{l}\text { Collinearity } \\
\text { Statistics } \\
\text { (VIF) }\end{array}$ \\
\hline 1 & $\begin{array}{c}\text { (Constant) } \\
\text { Price inflation rate Ro } \\
\text { Unemployment rate Ro }\end{array}$ & 0.457 & 11.525 & 0.000 & $\begin{array}{l}-0.697 \\
-0.168\end{array}$ & $\begin{array}{l}0.000 \\
0.000 \\
0.266\end{array}$ & $\begin{array}{l}0.000 \\
0.000 \\
0.266\end{array}$ & $\begin{array}{l}1.003 \\
1.003\end{array}$ \\
\hline 2 & $\begin{array}{c}\text { (Constant) } \\
\text { Price inflation rate Ro }\end{array}$ & 0.450 & 1.297 & 0.266 & -0.687 & $\begin{array}{l}11.894 \\
-4.635\end{array}$ & $\begin{array}{l}0.000 \\
0.000\end{array}$ & 1.000 \\
\hline
\end{tabular}

The VIF value (1.003 for the model 1 and 1.000 for the model 2 ) indicates that we do not have a multicollinearity problem.

The adjusted R Square value for the model 1, which includes all the variables, illustrates that $45.7 \%$ of the variance in the number of Romanian migrants in EU28 was explained by the combination of the two variables (price inflation rate and unemployment rate). Furthermore, the model 2 illustrates that $45 \%$ of the variance in the number of Romanian migrants in EU28 was explained by the price inflation rate.

Hypotheses 2 (H2). The unemployment rate and income inequality (Gini index) explain the number of definitive migrants in EU28 from Romania and Bulgaria.

Hypotheses 2.0. (H2.0.). The unemployment rate and income inequality (Gini index) cannot explain the number of definitive migrants in the EU28 from Romania and Bulgaria.

The Table 9 shows the relevance of the regression model. According to the $\mathrm{F}$ value obtained $(p<0.001)$ for the two models, the null hypothesis can be rejected in the case of Romania and Bulgaria. 
Table 9. Assessing the Quality of the Regression Model.

\begin{tabular}{|c|c|c|c|c|c|}
\hline Case & Model & Sum of Squares & Sum of Squares & $\mathbf{F}$ & Anova Sig. \\
\hline \multirow{4}{*}{ Ro } & \multirow{3}{*}{1} & Regression & $1.954 \times 10^{13}$ & \multirow{3}{*}{333.760} & \multirow{3}{*}{$0.000^{\mathrm{a}}$} \\
\hline & & Residual & $6.733 \times 10^{11}$ & & \\
\hline & & Total & $2.022 \times 10^{13}$ & & \\
\hline & \multirow{3}{*}{2} & Regression & $1.949 \times 10^{13}$ & \multirow{3}{*}{647.742} & \multirow{3}{*}{$0.000^{b}$} \\
\hline \multirow[t]{3}{*}{ Ro } & & Residual & $7.222 \times 10^{11}$ & & \\
\hline & & Total & $2.022 \times 10^{13}$ & & \\
\hline & \multirow{3}{*}{1} & Regression & $7.074 \times 10^{11}$ & \multirow{3}{*}{1987.677} & \multirow{3}{*}{$0.000^{\mathrm{a}}$} \\
\hline \multirow[t]{3}{*}{$\mathrm{Bu}$} & & Residual & $4.093 \times 10^{9}$ & & \\
\hline & & Total & $7.115 \times 10^{11}$ & & \\
\hline & \multirow{3}{*}{2} & Regression & $7.073 \times 10^{11}$ & \multirow{3}{*}{4097.683} & \multirow{3}{*}{$0.000^{\mathrm{b}}$} \\
\hline \multirow[t]{2}{*}{$\mathrm{Bu}$} & & Residual & $4.143 \times 10^{9}$ & & \\
\hline & & Total & $7.115 \times 10^{11}$ & & \\
\hline
\end{tabular}

a Predictors: (Constant), GINI.Ro/Bu, Unemployment rate Ro/Bu; ${ }^{\mathrm{b}}$ Predictors: (Constant), GINI.Ro/Bu; Dependent Variable: Total.Migrants.Ro/Bu.

We can see in Table 10 that the initial model which includes all the variables considered (model 1), such as unemployment rate and Gini index and model 2 which considered only one variable- the Gini index (we consider the backward elimination criterion-the probability of $\mathrm{F}$ to remove $\geq 0.10$ ).

Table 10. Testing the effects of unemployment rate and Gini Index on the total of definitive migrants in EU28 from Romania and Bulgaria.

\begin{tabular}{|c|c|c|c|c|c|c|c|c|}
\hline Model & R Square & $\begin{array}{l}\text { Adjusted } \\
\text { R Square }\end{array}$ & $\begin{array}{c}\text { F } \\
\text { Change }\end{array}$ & $\begin{array}{l}\text { Sig. F } \\
\text { Change }\end{array}$ & $\begin{array}{l}\text { Standardised } \\
\text { Coefficients } \\
\text { Beta }\end{array}$ & $t$ & Sig & $\begin{array}{c}\text { Collinearity } \\
\text { Statistics(VIF) }\end{array}$ \\
\hline \multirow[t]{2}{*}{1} & Unemployment rate Ro & \multirow[t]{2}{*}{0.964} & \multirow[t]{2}{*}{333.760} & \multirow[t]{2}{*}{0.000} & 0.050 & 0.982 & 0.209 & 0.000 \\
\hline & GINI. Ro & & & & 0.991 & 0.982 & 0.000 & 0.209 \\
\hline 2 & (Constant) & 0.963 & 1.671 & 0.209 & 0.982 & -22.617 & 0.000 & \\
\hline \multirow{3}{*}{1} & (Constant) & \multirow{3}{*}{0.994} & \multirow{3}{*}{1987.677} & \multirow{3}{*}{0.000} & & -53.176 & 0.000 & \\
\hline & Unemployment rate $\mathrm{Bu}$ & & & & -0.009 & -0.531 & 0.601 & 1.070 \\
\hline & GINI. Bu & & & & 0.995 & 60.819 & 0.000 & 1.070 \\
\hline \multirow{2}{*}{2} & (Constant) & \multirow{2}{*}{0.994} & \multirow{2}{*}{0.282} & \multirow{2}{*}{0.601} & \multirow{2}{*}{0.997} & -58.709 & 0.000 & \\
\hline & GINI. Bu & & & & & 64.013 & 0.000 & 1.000 \\
\hline
\end{tabular}

We can see that the unemployment rate is the variable with an insignificant contribution to the first model in the case of Romania and Bulgaria. In addition, the standardised coefficient Beta of this variable are 0.05 in the case of Romania and -0.009 in the case of Bulgaria, which is not statistically significant (i.e., the $t$-value is not significant with a value of 0.209 for Romania and 0.601 for Bulgaria $\geq 0.10$ ) representing an insignificant contribution to explain the dependent variable-number of migrants in EU28 - and it was removed from the final model (model 2). The VIF value of the model 2 (1.000 for Romania and Bulgaria) indicates that we do not have a multicollinearity problem.

Furthermore, the variable Gini index presents a beta value of 0.991 for Romania and 0.995 for Bulgaria (model 1) and indicates that by each 1-unit increase in the predictor variable, the outcome variable will increase by 0.991 units for Romania and 0.995 units for Bulgaria. These values indicate that the income inequalities explain in majority the variance of the definitive migrants in EU28 in the case of Romania and Bulgaria.

We may conclude that the variable Gini index (income inequality) explains by $96.3 \%$ (model 2) the number of definitive migrants in EU28 in the case of Romania and by $99.4 \%$ in the case of Bulgaria (model 2). 
Hypotheses 3 (H3). The household consumption expenditure and GDP growth rate/capita explain the number of definitive migrants in EU28 from Romania and Bulgaria.

Hypotheses 3.0. (H3.0.). The household consumption expenditure and GDP growth rate/capita cannot explain the number of definitive migrants in EU28 from Romania and Bulgaria.

Table 11 shows that according to the F value obtained $(p<0.001)$, the null hypothesis can be rejected in the case of Romania and Bulgaria.

Table 11. Assessing the Quality of the Regression Model.

\begin{tabular}{|c|c|c|c|c|c|}
\hline Case & Model & Sum of Squares & Sum of Squares & F & Anova Sig. \\
\hline Ro & 1 & $\begin{array}{c}\text { Regression } \\
\text { Residual } \\
\text { Total } \\
\end{array}$ & $\begin{array}{l}1.865 \times 10^{13} \\
1.566 \times 10^{12} \\
2.022 \times 10^{13}\end{array}$ & 136.966 & $0.000^{\mathrm{a}}$ \\
\hline Ro & 2 & $\begin{array}{l}\text { Regression } \\
\text { Residual } \\
\text { Total } \\
\end{array}$ & $\begin{array}{l}1.865 \times 10^{13} \\
1.566 \times 10^{12} \\
2.022 \times 10^{13}\end{array}$ & 285.765 & $0.000^{b}$ \\
\hline $\mathrm{Bu}$ & 1 & $\begin{array}{c}\text { Regression } \\
\text { Residual } \\
\text { Total }\end{array}$ & $\begin{array}{l}6.765 \times 10^{11} \\
3.492 \times 10^{10} \\
7.115 \times 10^{11}\end{array}$ & 222.790 & $0.000^{\mathrm{a}}$ \\
\hline
\end{tabular}

a Predictors: (Constant), GDP.Growth.Rate/Capita.Ro/Bu, Household Consumption Expenditure Ro/Bu;

b Predictors: (Constant), Household Consumption Expenditure Ro/Bu; Dependent Variable: Total.Migrants.Ro/Bu.

We can see in Table 12 that the initial model for Romania includes all the variables considered (model 1), such as household consumption expenditure and GDP.Growth.Rate/capita and model 2 which considered only one variable- the household consumption expenditure (we consider the backward elimination criterion- the probability of $\mathrm{F}$ to remove $\geq 0.10$ ).

Table 12. Testing the effects of Household Consumption Expenditure and GDP.Growth.Rate/Capita. on the total of definitive migrants in EU28 from Romania and Bulgaria.

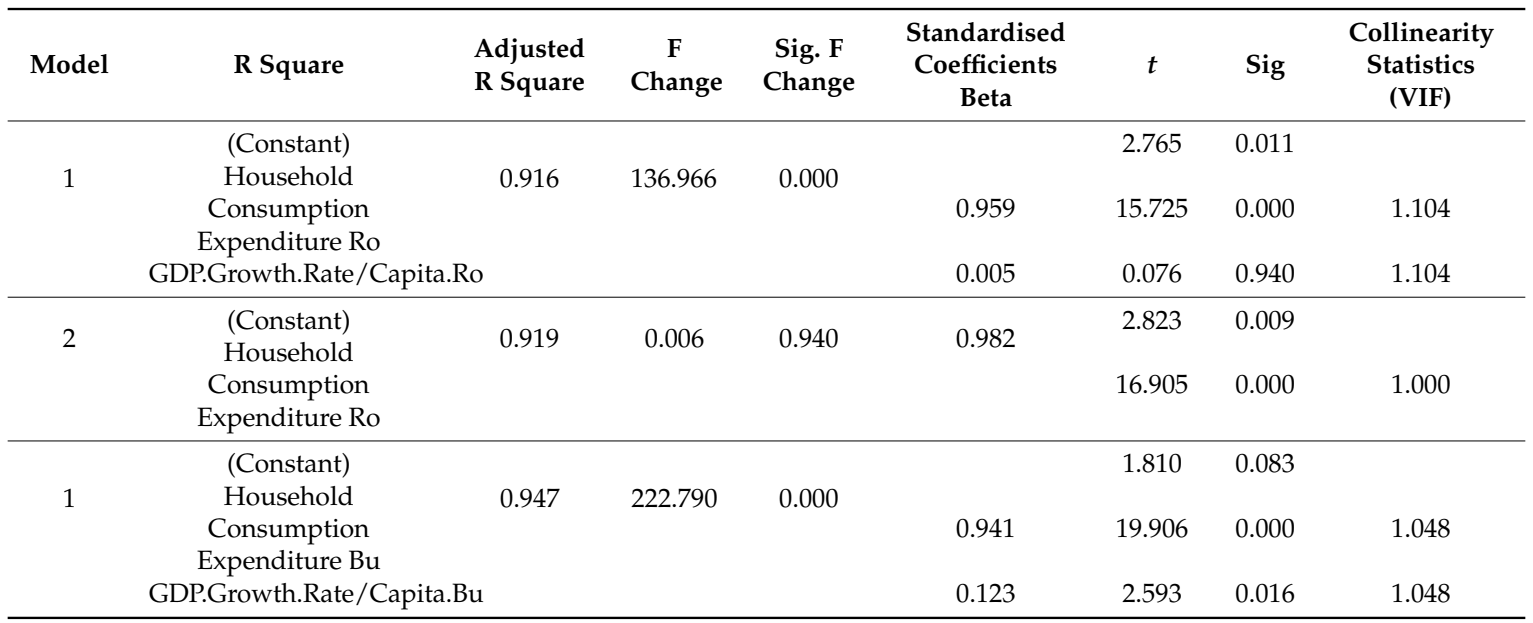

Predictors: (Constant), GDP.Growth.Rate/Capita.Ro/Bu, Household Consumption Expenditure Ro/Bu; Predictors: (Constant), Household Consumption Expenditure Ro/Bu; Dependent Variable: Total.Migrants. Ro/Bu.

We can see that the GDP.Growth.Rate/capita is a variable with an insignificant contribution in Romania. In addition, the standardized coefficient Beta of this variable is not statistically significant with a value of 0.005 in the case of Romania (i.e., the $t$-value is not significant with a value of 
$0.940 \geq 0.10$ ), which represent an insignificant contribution to explain the dependent variable-number of Romanian migrants in EU28 and it was removed from the final model (model 2).

In the case of Bulgaria we have only one model but we can see that the variance of the definitive migrants is explained in majority by the same variable as household consumption expenditure (the standardised coefficients Beta of this variable is 0.941 , which indicates that by each 1-unit increase in the predictor variable, the outcome variable will increase by only 0.941 units) as compared to the other variable which presents the standardised coefficient Beta of 0.123 , which indicates that by each 1 -unit increase in the predictor variable, the outcome variable will increase by only 0.123 units.

In both cases, the VIF value (1.000 for Romania and 1.048 for Bulgaria) indicate that we do not have a multicollinearity problem.

We can conclude that the variable Household Consumption Expenditure explains by $91.9 \%$ the number of definitive migrants in EU28 in the case of Romania and by $94.7 \%$ in the case of Bulgaria.

Data analysis confirmed that the inflation rate explains the number of definitive migrants in EU28 from Romania. In addition, the income inequality (Gini index) explains the number of definitive migrants in EU28 from Romania and Bulgaria. And finally, the household consumption expenditure explains the number of definitive migrants in EU28 from Romania and Bulgaria. The contribution of each these variables is very similar for Romania and Bulgaria.

In order to achieve our first objective of the present study, we can conclude that the main determinants of the migration process in Romania and Bulgaria are the inflation rate, the income inequality and the household consumption expenditure. However, because we manipulate economic indicators, we can see that many of them are highly correlated and they influence each other. For example, GDP growth rate (economic growth) has a linear correlation with the inflation rate and the unemployment rate, etc.

\subsection{The Impact of Remittances in Romania and Bulgaria}

Hypotheses $\mathrm{H} 4-\mathrm{H} 8$ were confirmed by running correlation analyses, by which we intended to determine the possible relationship between two variables, the intensity of the relationship and the direction of influence of a variable on the other.

Table 13 indicates the Pearson correlation for the variable remittances received/capita and the five variables considered in the study such as: GDP/capita growth rate, price inflation rate, unemployment rate, household final consumption, income inequality in Romania and Bulgaria.

Table 13. Correlation matrix-Remittances: Romania-Bulgaria.

\begin{tabular}{|c|c|c|c|c|c|c|}
\hline Variables/Pearsor & Correlation & $\begin{array}{l}\text { GDP.Growth. } \\
\text { Rate/Capita }\end{array}$ & $\begin{array}{c}\text { Price } \\
\text { Inflation Rate }\end{array}$ & $\begin{array}{c}\text { Unemployment } \\
\text { Rate }\end{array}$ & $\begin{array}{l}\text { Household Final } \\
\text { Consumption }\end{array}$ & GINI \\
\hline $\begin{array}{c}\text { Remittances } \\
\text { Received (ReR.Ro) } \\
\text { Sig. (2-tailed) }\end{array}$ & $\begin{array}{l}\text { Pearson } \\
\text { Correlation } \\
\text { Sig. (2-tailed) }\end{array}$ & $\begin{array}{l}0.151 \\
0.504\end{array}$ & $\begin{array}{l}-0.470 \text { * } \\
0.027\end{array}$ & $\begin{array}{l}-0.477^{*} \\
0.025\end{array}$ & $\begin{array}{l}0.759^{* *} \\
0.000\end{array}$ & $\begin{array}{c}0.718^{* *} \\
0.000\end{array}$ \\
\hline $\begin{array}{c}\text { Remittances } \\
\text { Received (ReR.Bu) } \\
\text { Sig. (2-tailed) }\end{array}$ & $\begin{array}{c}\text { Pearson } \\
\text { Correlation } \\
\text { Sig. (2-tailed) }\end{array}$ & $\begin{array}{l}0.308 \\
0.187\end{array}$ & $\begin{array}{l}-0.422 \\
0.064\end{array}$ & $\begin{array}{l}-0.539 * \\
0.014\end{array}$ & $\begin{array}{l}0.799 * * \\
0.000\end{array}$ & $\begin{array}{l}0.851^{* *} \\
0.000\end{array}$ \\
\hline
\end{tabular}

Hypotheses 4 (H4). There is a direct relationship between the remittances received/capita and GDP/capita growth rate in Romania and Bulgaria.

The study of the relationship between the remittances received/capita and GDP/capita growth rate was based on Pearson correlation analysis. According to Table 13, the relationship between the two variables may not be presented as direct, positive (the correlation coefficient value is 0.151 for Romania and 0.308 for Bulgaria), and it is not statistically significant for a confidence level of $99 \%$. Sig. coefficient value (0.504 for Romania and 0.187 for Bulgaria) higher than the accepted level of 0.05, 
statistically proves that there is not a direct connection between the remittances received/capita and $\mathrm{GDP} /$ capita growth rate.

The hypothesis $\mathrm{H} 4$ is not confirmed.

Hypotheses 5 (H5). There is a direct relationship between the remittances received/capita and price inflation rate in Romania and Bulgaria.

The study of the relationship between the remittances received/capita and price inflation rate was based on Pearson correlation analysis. According to Table 13, the relationship between the two variables may be presented as direct, negative, with average intensity (the correlation coefficient value is -0.470 ) and statistically significant for a confidence level of $95 \%$. Sig. coefficient value (0.027), lower than the accepted level of 0.05 , confirms the start hypothesis and statistically proves that there is a direct connection between the remittances received/capita and price inflation rate in Romania.

For Bulgaria, the correlation coefficient value is -0.422 and it is not statistically significant for a confidence level of $99 \%$. Sig. coefficient value (0.064), higher than the accepted level of 0.05 , statistically proves that there is not a direct connection between the remittances received/capita and price inflation rate. We recall the hyperinflation episode in Bulgaria in 1991 and 1997 which influenced the statistical data.

H5 is confirmed for the case of Romania.

Hypotheses 6 (H6). There is a direct relationship between the remittances received/capita and unemployment rate in Romania and Bulgaria.

The study of the relationship between the remittances received/capita and unemployment rate was based on Pearson correlation analysis. According to Table 13, the relationship between the two variables may be presented as direct, negative, with average intensity (the correlation coefficient value is -0.477 for Romania and -0.539 for Bulgaria) and statistically significant for a confidence level of $95 \%$. Sig. coefficient value ( 0.025 for Romania and 0.014 for Bulgaria), lower than the accepted level of 0.05 , confirms the start hypothesis and statistically proves that there is a direct connection between the remittances received/capita and unemployment rate in Romania and Bulgaria.

H6 is confirmed for Romania and Bulgaria.

Hypotheses 7 (H7). There is a direct relationship between the remittances received/capita and household final consumption in Romania and Bulgaria.

The study of the relationship between the remittances received/capita and household final consumption was based on Pearson correlation analysis. According to Table 13, the relationship between the two variables may be presented as direct, positive, with high intensity (the correlation coefficient value is 0.759 for Romania and 0.799 for Bulgaria) and statistically significant for a confidence level of $99 \%$. Sig. coefficient value (0.000 for Romania and 0.000 for Bulgaria), lower than the accepted level of 0.01 , confirms the start hypothesis and statistically proves that there is a direct connection between the remittances received/capita and household final consumption in Romania and Bulgaria.

$\mathrm{H} 7$ is confirmed for Romania and Bulgaria.

Hypotheses 8 (H8). There is a direct relationship between the remittances received/capita and Gini index (income inequality) in Romania and Bulgaria.

The study of the relationship between the remittances received/capita and Gini index (income inequality) was based on Pearson correlation analysis. According to Table 13, the relationship between the two variables may be presented as direct, positive, with high intensity (the correlation coefficient value is 0.718 for Romania and 0.851 for Bulgaria) and statistically significant for a confidence level of 
$99 \%$. Sig. coefficient value (0.000 for Romania and 0.000 for Bulgaria), lower than the accepted level of 0.01 , confirms the start hypothesis and statistically proves that there is a direct connection between the remittances received/capita and Gini index (income inequality) in Romania and Bulgaria.

H8 is confirmed for Romania and Bulgaria.

Data analysis shows that there is not a direct relationship between the remittances received/capita and GDP/capita growth rate in Romania and Bulgaria.

In addition, there is a direct relationship (negative and with average intensity) between the remittances received/capita and price inflation rate in Romania but not in Bulgaria.

In the case of Romania and Bulgaria we find that there is a direct relationship with similar intensity between the remittances received/capita and the unemployment rate, the household final consumption and finally the income inequality.

\section{Discussion}

Romania and Bulgaria are two very similar countries, as we previously mentioned. Both belong to the Central and Eastern European block, characterised by massive migration flows towards the developed states of the EU28. Migration flows have positive and negative effects on the countries of origin and on the host countries, which are different on short and long term. The focus of the present analysis is on remittances, income sent by emigrants to their country of origin, which on short term influences positively the economy and the society. Remittances are used for subsistence expenditure, also for investments, especially in the field of real estate and education. However, on long term, remittances associated with an increasing number of emigrants economically affect sustainability, because the deficit of active labour will be compensated by activities involving the almost abusive use of other resources and environmental destruction.

The economic stability-sustainability is the main goal of every country administration and at the same time it is a common goal in EU28.

In the case of Romania, migration effects are not entirely negative. Romania is currently the second emigrant sending country after Syria and the Romanian exodus has been high for years $[99,100]$. The social categories of Romanian migrants are extremely varied, from people who are highly educated and well trained professionally [101], to people with extremely limited formal education [102]. Regardless of the Romanian migrants' professional status, the causes of their decision to migrate are generally the economic and social deprivation. Romanian migrants seek opportunities to raise their income and their standard of living, as well as the safety of their jobs and these objectives are reached both legally and illegally.

Most of the highly educated Romanian migrants leave the country legally. They find a place to work before leaving the country and when they leave their place of origin, they are certain that the activity they are going to perform is according to their education and professional abilities. The migrants with high degree of formal education intrinsically intend that the position they occupy abroad will offer them the expected income, the desired work conditions, possibilities of professional development and safety, all these being important factors in their decision to migrate. The exodus of the people with good formal education constitutes the so-called brain-drain flow, which according to Haller $[100,103-105]$ is an economic and social loss for any country investing in the educational process of its people, and not recovering its investment. The more years for the formal education, the greater the loss. The state will indirectly recover some of this investment by the money which the migrants re-send to the country, that is, by remittances. The probability that the value of remittances is higher than the value of investments in education is low, so that the brain-drain phenomenon becomes a loss for economy and society, especially that a small part of the migrants in this category return to their country of origin. It is usually a form of definitive migration, because well trained people find in the destination countries what they lack in their country of origin: good work conditions, professional development opportunities, high degree of civilisation. The professionally well-trained migrants 
constitute the social category which has no problems in finding a job in their country, they only have problems in finding an adequate place of work, also from a financial perspective.

Most of the Romanian migrants with low training and education leave the country illegally. They assume major risks, because they do not have the certitude of getting a job, so that they do not have great expectations and they accept to perform almost any activity as long as it is paid. Their objective is to earn higher incomes than they used to earn in their own countries and to re-send them home as remittances with the purpose to consolidate their material position, with the belief that they might return. This category of migrants frequently change their work place in the destination country as they adapt and have the possibility to earn increasingly higher incomes. The migrants with average and low formal education send to their countries the highest volume of remittances due to the certainty of definitive return, with the objective to consolidate their material position. The people who emigrate illegally have difficulties in finding a safe job, in re-qualifying and even in adapting to the conditions in the destination countries, so that they become aware of the fact that at a certain point they will need to return to their country. On long term, migration attracts negative effects to Romania. The more the phenomenon is perpetuated, the more it erodes the economy and the society. The decrease of the number of active population will chronically unbalance the labour market. The demographic pyramid will not be reversed as a result of the aging process associated with the effects of growth specific to developed countries but as a result of a higher and more accelerated exodus of the young population fit for work, on the background of a demographic decrease. After graduation, many young people intend to find a job in one of the countries where their diplomas are recognised. According to our analysis, the volume of remittances in both countries highly explains the degree of income inequality. The number of remittances in Romania and Bulgaria is alarming and it should be one of the main concerns of their governments in order to align these two countries to the requirements of the European Union.

In Romania there are no perspectives for migration to stop, only to lower, providing that there is a fast and efficient implication of the state by complex measures of economic policy. The low income and standard of living will maintain the migration phenomenon in Romania and the effects will prove increasingly complex by their multiplication effect (low income, low investments, labour market unbalance, unemployment, etc.), which will maintain the migration, especially the definitive one, lowering the positive impact by contracting the value of remittances. However, on long term, there will be negative effects of the migration phenomenon on the economy and on Romanian society and the problems associated with migration will involve complex structural measures in almost all the fields and sectors, including the behaviour of the political decision-making factors for which the population manifests a deficit of trust.

The Bulgarians' migration has positive economic and demographic consequences by reducing the pressures on the labour market and the poverty, by stimulating entrepreneurship by increasing the number of small enterprises as an effect of remittances. It also has negative consequences, because brain-drain migration involves highly qualified people who are leaving the country, depopulation of peripheral regions, family division [81]. Like the Romanian migrants, Bulgarians strive to obtain material safety. Remittances are mainly destined for consumption expenditure but also for investments, especially in the field of real estate. The critical economic fund stimulates Bulgarians' migration; however, the volume of remittances is lower than the Romanian one, which may be also explained by the demographic differences. We must mention that Bulgaria made a significant economic progress, which will be reflected in the future migration flows. At present, the effects of migration are similar to those of the Romanian economy. Migration also unbalances the Bulgarian labour market and modifies the demographic balance, on long term straining the Bulgarian economy due to the lower capacity to support sustainability. Young Bulgarians seek development opportunities outside their country of origin, which means a loss on the segment of qualified people, which also has a negative impact on economy and society on average and especially on long term. 
In both countries, remittances represent income from external sources with positive short-term and negative long-term effects. If we consider the economic and environmental consequences, that is, the fact that in the future a sustainable development will be difficult to support, the advantages offered by remittances on short term do not compensate the long-term disadvantages. The microeconomic objectives-the income growth and financial safety-do not overlap the macroeconomic ones, which converge towards sustainable development.

For the receiving states, the emigrants coming from the East European states, Ukraine, Romania, Bulgaria and Moldova compensate the loss of workforce from the developed markets as a result of population aging and offer the possibility to use the cheaper and less qualified or highly qualified workforce [106] but willing to perform such a work where the native population is not willing to. However, the problem of stay and of illegal work is relevant in the case of Romanian and Bulgarian migrants [107].

\section{Conclusions}

This study aimed to identify (1) the factors determining migration and (2) the impact of remittances - the income sent by emigrants to their country of origin-on the economic growth and income inequality in the case of Romania and Bulgaria for the period between 1990-2015.

For the empirical analysis, we used indicators from three different sources, UN, Eurostat and the World Bank, with the purpose of obtaining a full picture of the situations studied.

The authors proposed eight hypotheses to be tested in order to highlight the main aspects of Romanian and Bulgarian migration singularity and their effects on the economic/social stability-sustainability.

$\mathrm{H} 1-\mathrm{H} 3$ hypotheses were tested with the help of the multiple regression model and $\mathrm{H} 4-\mathrm{H} 8$ hypotheses were tested with the help of the bivariate correlation — based on Pearson correlation analysis.

Data analysis confirmed that the inflation rate explains the number of definitive migrants in EU28 from Romania. In addition, the income inequality (Gini index) explains the number of definitive migrants in EU28 from Romania and Bulgaria. And finally, the household consumption expenditure explains the number of definitive migrants in EU28 from Romania and Bulgaria. The contribution of these variables is very similar for Romania and Bulgaria.

In order to achieve our first objective of the present study, we can conclude that the main determinants of the migration process in Romania and Bulgaria are the inflation rate, the income inequality and the household consumption expenditure. However, because we manipulate economic indicators, we can see that many of them are highly correlated and they have an influence on each other. For example, GDP growth rate (economic growth) had linear correlation with the inflation rate and with the unemployment rate and so forth.

In order to achieve our second objective, we can conclude that there is no direct relationship between the remittances received/capita and GDP/capita growth rate in Romania and Bulgaria.

In addition, there is a direct (negative) relationship between the remittances received/capita and price inflation rate in Romania, though not also in Bulgaria, with average and similar intensity in both cases.

In Romania and Bulgaria there is a direct relationship with similar intensity between the remittances received/capita and the unemployment rate (negative relation, average intensity but higher in the case of Bulgaria), the household final consumption and finally with the income inequality (positive with high intensity and very similar for both countries).

The analysis of the relationship between remittances and economic growth and between remittances and inflation, unemployment and income inequality indicates some of the factors determining Romanians' and Bulgarians' migration. The non-manifestation of a direct relationship between remittances and economic growth highlights that in Romania and Bulgaria migration is not necessarily a factor of economic stimulation but rather a consequence of the deficiencies manifested in economy like inflation, unemployment and income inequality. This paper may constitute a starting point for future studies of this phenomenon, including the comparison to other developing states. 
It may also be an inspiration for the decision-makers in economic policy to help them establish the measures necessary for the decrease of the migrants' flow from Romania and Bulgaria towards EU28, because it highlights three of the main factors determining the phenomenon and demonstrates that the value of remittances does not have a direct impact on the economic growth. According to the conclusions of this analysis, countries like Romania and Bulgaria may redirect their attention towards solving the internal problems which are mostly related to phenomena with major implications in economy, like inflation, unemployment and income inequality, because they are the main causes of migration. The demographic contraction in Romania and Bulgaria will not be compensated by the positive effect of remittances but it might be stopped by the implementation of measures to balance the labour and monetary market and to improve the standard of living.

Acknowledgments: The authors would like to thank the anonymous reviewers and the editors for their valuable comments and suggestions to improve the quality of the paper.

Author Contributions: All authors contributed equally to all aspects of the research reported in this paper.

Conflicts of Interest: The authors declare no conflict of interest.

\section{Appendix A}

Table A1. Migration profile of Romania vs. Bulgaria.

\begin{tabular}{|c|c|c|c|c|c|c|c|c|}
\hline & \multicolumn{4}{|c|}{ Migration Profile-Romania } & \multicolumn{4}{|c|}{ Migration Profile-Bulgaria } \\
\hline & 1990 & 2000 & 2010 & 2013 & 1990 & 2000 & 2010 & 2013 \\
\hline Males (‘000) & 11,510 & 10,930 & 10,655 & 10,569 & 4349 & 3898 & 3597 & 3510 \\
\hline Females ('000) & 11,862 & 11,458 & 11,206 & 11,130 & 4472 & 4102 & 3792 & 3713 \\
\hline Total (‘000) & 23,372 & 22,388 & 21,861 & 21,699 & 8821 & 8001 & 7389 & 7223 \\
\hline $\begin{array}{l}\text { Percentage of urban } \\
\text { population }(\%)\end{array}$ & 53 & 53 & 53 & 53 & 66 & 69 & 73 & 74 \\
\hline \multirow[t]{2}{*}{$\begin{array}{l}\text { Percentage of rural } \\
\text { population }(\%)\end{array}$} & 47 & 47 & 47 & 47 & 34 & 31 & 27 & 26 \\
\hline & 1985-1990 & 1995-2000 & 2005-2010 & 2010-2015 & $1985-1990$ & 1995-2000 & 2005-2010 & 2010-2015 \\
\hline $\begin{array}{l}\text { Annual rate of } \\
\text { natural increase }\end{array}$ & 5.15 & -2.18 & -1.79 & -2.19 & 1.01 & -6.14 & -5.6 & -6.25 \\
\hline \multirow[t]{2}{*}{ Total net migration ('000) } & -121 & -328 & -55 & -45 & -184 & -107 & -83 & -50 \\
\hline & $2015-2020$ & $2025-2030$ & $2035-2040$ & $2045-2050$ & $2015-2020$ & $2025-2030$ & $2035-2040$ & $2045-2050$ \\
\hline $\begin{array}{l}\text { Total population at the end } \\
\text { of the period }\end{array}$ & 21,226 & 20,232 & 19,056 & 17,809 & 6827 & 6213 & 5611 & 5077 \\
\hline \multirow[t]{2}{*}{$\begin{array}{c}\text { Annual rate of } \\
\text { natural increase }\end{array}$} & -2.88 & -4.81 & -5.7 & -6.53 & -6.76 & -8.28 & -8.39 & -8.17 \\
\hline & 1990 & 2000 & 2010 & 2012 & 1990 & 2000 & 2010 & 2012 \\
\hline $\begin{array}{l}\text { Remittances- Inflows } \\
\text { (millions of US dollars) }\end{array}$ & - & 96 & 3952 & 3669 & - & 58 & 1333 & 1376 \\
\hline $\begin{array}{l}\text { Remittances-Outflows } \\
\text { (millions of US dollars) }\end{array}$ & - & 6 & 360 & 363 & - & 26 & 25 & 26 \\
\hline $\begin{array}{l}\text { Remittances-Inflows as } \\
\text { share of GDP (\%) }\end{array}$ & - & 0.3 & 2.4 & 2.2 & - & 0.5 & 2.8 & 2.7 \\
\hline
\end{tabular}

Note: ('000)—per 1000 population. Source: [84-86].

Table A2. Definitive migrants according to the destination country. Data for Romania (total number of people).

\begin{tabular}{cccccccc}
\hline Year & $\mathbf{1 9 9 0 - 1 9 9 4}$ & $\mathbf{1 9 9 5 - 1 9 9 9}$ & $\mathbf{2 0 0 0 - 2 0 0 4}$ & $\mathbf{2 0 0 5 - 2 0 0 9}$ & $\mathbf{2 0 1 0 - 2 0 1 2}$ & $\mathbf{2 0 1 3}$ & $\mathbf{2 0 1 4 - 2 0 1 5}$ \\
\hline Austria & 24,968 & 28,168 & 31,368 & 45,724 & 60,079 & 62,801 & 70,267 \\
Belgium & 2257 & 2326 & 2401 & 9234 & $\mathbf{2 8 , 3 0 3}$ & $\mathbf{2 9 , 3 2 8}$ & 57,125 \\
Bulgaria & 143 & 1393 & 2642 & 4308 & 5968 & 6371 & 5660 \\
Croatia & 0 & 166 & 0 & 405 & 0 & 0 & 499 \\
Cyprus & 1345 & 1902 & 2459 & 3599 & 4737 & 6367 & 6024 \\
Czech Republic & 2945 & 4417 & 5889 & 5109 & 4545 & 4636 & 5125 \\
Denmark & 877 & 1435 & 1992 & 4233 & 6473 & 13,615 & 13,999 \\
\hline
\end{tabular}


Table A2. Cont.

\begin{tabular}{cccccccc}
\hline Year & $\mathbf{1 9 9 0 - 1 9 9 4}$ & $\mathbf{1 9 9 5 - 1 9 9 9}$ & $\mathbf{2 0 0 0 - 2 0 0 4}$ & $\mathbf{2 0 0 5 - 2 0 0 9}$ & $\mathbf{2 0 1 0 - 2 0 1 2}$ & $\mathbf{2 0 1 3}$ & $\mathbf{2 0 1 4 - 2 0 1 5}$ \\
\hline Estonia & 0 & 0 & 0 & 0 & 0 & 0 & 59 \\
Finland & 157 & 375 & 593 & 1164 & 1734 & 2182 & $\mathbf{2 9 7 6}$ \\
France & 31,928 & 32,961 & 33,993 & 43,381 & 63,557 & 65,700 & 89,793 \\
Germany & 176,920 & 249,921 & 322,922 & 446,724 & 379,293 & 383,626 & 590,189 \\
Greece & 3979 & 16,015 & 21,197 & 36,759 & 37,290 & 38,597 & 46,193 \\
Hungary & 194,128 & 170,168 & 146,210 & 180,592 & 214,976 & 232,793 & 204,603 \\
Ireland & 430 & 2334 & 6060 & 13,632 & 11,399 & 19,566 & 19,919 \\
Italy & 40,066 & 79,401 & 118,736 & 570,087 & 846,826 & $1,008,169$ & $1,021,613$ \\
Latvia & 3562 & 1815 & 69 & 191 & 340 & 128 & 260 \\
Lithuania & 35 & 40 & 31 & 130 & 39 & 27 & 181 \\
Luxembourg & 106 & 203 & 295 & 717 & 1120 & 1575 & 1742 \\
Netherlands & 1678 & 2804 & 4139 & 6314 & 11,168 & 13,606 & 14,757 \\
Malta & 76 & 89 & 215 & 351 & 421 & 493 & 791 \\
Poland & 4748 & 4061 & 3467 & 2977 & 2748 & 2659 & 2480 \\
Portugal & 819 & 1766 & 2717 & 12,468 & 22,469 & 23,513 & 22,038 \\
Romania & - & - & - & - & - & - & - \\
Slovakia & 1115 & 2843 & 3196 & 6003 & 5364 & 4890 & 8152 \\
Slovenia & 63 & 93 & 126 & 181 & 316 & 352 & 524 \\
Spain & 2167 & 4375 & 8489 & 292,379 & 740,875 & 797,603 & 658,132 \\
Sweden & 9253 & 10,980 & 11,776 & 12,748 & 19,741 & 22,526 & 25,223 \\
United & 3987 & 5579 & 36,617 & 41,778 & 77,670 & 103,421 & 89,402 \\
Kingdom & & & & & & & \\
\hline
\end{tabular}

Source: [86].

Table A3. Definitive emigrants according to the destination country. Data for Bulgaria (total number of people).

\begin{tabular}{cccccccc}
\hline Year & $\mathbf{1 9 9 0 - 1 9 9 4}$ & $\mathbf{1 9 9 5 - 1 9 9 9}$ & $\mathbf{2 0 0 0 - 2 0 0 4}$ & $\mathbf{2 0 0 5 - 2 0 0 9}$ & $\mathbf{2 0 1 0 - 2 0 1 2}$ & $\mathbf{2 0 1 3}$ & $\mathbf{2 0 1 4 - 2 0 1 5}$ \\
\hline Austria & 8666 & 9777 & 10,888 & 12,170 & 13,452 & 14,061 & 15,733 \\
Belgium & 907 & 976 & 1048 & 4126 & 14,129 & 14,641 & 26,415 \\
Bulgaria & - & - & - & - & - & - & - \\
Croatia & 0 & 138 & 0 & 283 & 0 & 0 & 305 \\
Cyprus & 1531 & 2165 & 2799 & 4097 & 5392 & 7247 & 6857 \\
Czech Republic & 1154 & 1731 & 2308 & 4421 & 6973 & 7113 & 8768 \\
Denmark & 224 & 445 & 666 & 1760 & 2853 & 5457 & 5611 \\
Estonia & 0 & 0 & 0 & 0 & 0 & 0 & 72 \\
Finland & 274 & 348 & 421 & 793 & 1164 & 1492 & 2271 \\
France & 9404 & 9708 & 10,012 & 13,222 & 16,767 & 17,332 & 17,626 \\
Germany & 27,077 & 30,146 & 33,214 & 67,518 & 65,255 & 66,001 & 105,331 \\
Greece & 4994 & 22,834 & 34,214 & 56,513 & 54,092 & 55,988 & 72,893 \\
Hungary & 1962 & 1696 & 1430 & 1766 & 2102 & 2276 & 1397 \\
Ireland & 178 & 494 & 1187 & 1642 & 1352 & 1952 & 1974 \\
Italy & 446 & 5423 & 10,400 & 34,041 & 44,617 & 57,794 & 57,691 \\
Latvia & 390 & 220 & 50 & 297 & 589 & 513 & 451 \\
Lithuania & 33 & 37 & 29 & 59 & 128 & 88 & 71 \\
Luxembourg & 42 & 68 & 94 & 334 & 566 & 796 & 880 \\
Netherlands & 833 & 1217 & 1693 & 3111 & 13,501 & 18,044 & 18,714 \\
Malta & 77 & 91 & 221 & 361 & 433 & 507 & 1055 \\
Poland & 2415 & 2064 & 1762 & 1752 & 1916 & 1854 & 1730 \\
Portugal & 183 & 395 & 609 & 2831 & 5113 & 5350 & 5014 \\
Romania & 25,599 & 21,944 & 19,404 & 18,833 & 20,290 & 18,271 & 11,154 \\
Slovakia & 362 & 790 & 1039 & 1612 & 1223 & 1115 & 2190 \\
Slovenia & 65 & 75 & 88 & 122 & 794 & 949 & 1210 \\
Spain & 1095 & 1959 & 3678 & 86226 & 154,389 & 160,832 & 130,116 \\
Sweden & 2756 & 3271 & 3508 & 3962 & 6652 & 7506 & 8513 \\
United & 1722 & 3395 & 18,207 & 24,672 & 51,125 & 58,366 & 51,875 \\
Kingdom & & & & & & &
\end{tabular}


Table A4. SPSS database for Romania and Bulgaria.

\begin{tabular}{|c|c|c|c|c|c|c|c|c|}
\hline Year & $\begin{array}{c}\text { GDP/ } \\
\text { Capita.Ro }\end{array}$ & $\begin{array}{c}\text { GDP/ } \\
\text { Capita.Bu }\end{array}$ & $\begin{array}{c}\text { Price } \\
\text { Inflation } \\
\text { Rate.Ro }\end{array}$ & $\begin{array}{c}\text { Price } \\
\text { Inflation } \\
\text { Rate.Bu }\end{array}$ & $\begin{array}{c}\text { Unemployment } \\
\text { Rate.Ro }\end{array}$ & $\begin{array}{c}\text { Unemployment } \\
\text { Rate.Bu }\end{array}$ & $\begin{array}{l}\text { Household Final } \\
\text { Consumption.Ro }\end{array}$ & $\begin{array}{l}\text { Household Final } \\
\text { Consumption.Bu }\end{array}$ \\
\hline 1990 & -7.58 & -7.4632 & 127.9 & 23.9 & 3.4 & 2.9 & $25,690,909,091$ & $12,345,000,000$ \\
\hline 1991 & -12.1584 & -7.5341 & 161.1 & 333.5 & 3.5 & 6.8 & $17,613,157,895$ & $5,921,451,613$ \\
\hline 1992 & -7.9392 & -6.2713 & 210.4 & 82 & 5.4 & 13.2 & $15,756,250,000$ & $6,791,494,845$ \\
\hline 1993 & 1.6671 & -0.6912 & 256.1 & 72.8 & 9.2 & 15.8 & $16,793,026,316$ & $7,958,768,116$ \\
\hline 1994 & 4.0831 & 2.1644 & 136.7 & 96 & 11 & 14.1 & $19,094,017,523$ & $7,179,520,295$ \\
\hline 1995 & 7.3552 & 3.3193 & 32.3 & 62.1 & 9.9 & 11.4 & $25,889,326,119$ & $8,561,428,571$ \\
\hline 1996 & 4.1695 & 2.1253 & 38.8 & 123 & 7.3 & 11 & $27,031,787,220$ & $7,475,340,079$ \\
\hline 1997 & -4.5417 & -0.4961 & 154.8 & 1061.2 & 7.9 & 14 & $25,863,141,741$ & $7,464,520,483$ \\
\hline 1998 & -1.8844 & 4.193 & 59.1 & 18.7 & 9.6 & 12.4 & $32,272,307,346$ & $8,750,352,193$ \\
\hline 1999 & -0.2451 & -5.0793 & 45.67 & 2.6 & 7.2 & 13.8 & $25,930,672,406$ & $8,874,817,979$ \\
\hline 2000 & 2.5277 & 5.5309 & 45.67 & 10.32 & 7.6 & 18.1 & $25,568,105,394$ & $8,696,447,511$ \\
\hline 2001 & 7.0758 & 6.344 & 34.47 & 7.36 & 7.3 & 17.5 & $28,106,087,196$ & $9,611,249,142$ \\
\hline 2002 & 7.1275 & 8.3446 & 22.54 & 5.81 & 8.3 & 17.4 & $31,553,622,750$ & $11,060,933,077$ \\
\hline 2003 & 6.2881 & 5.9132 & 15.27 & 2.16 & 7.8 & 13.9 & $39,405,421,687$ & $14,201,585,964$ \\
\hline 2004 & 8.9778 & 7.3629 & 11.88 & 6.35 & 8 & 12.2 & $52,328,400,282$ & $17,672,169,386$ \\
\hline 2005 & 4.8172 & 8.0467 & 8.99 & 5.04 & 7.2 & 10.2 & $68,965,370,491$ & $20,304,802,744$ \\
\hline 2006 & 8.6976 & 7.567 & 6.58 & 7.26 & 7.1 & 9 & $84,565,717,337$ & $22,735,174,117$ \\
\hline 2007 & 8.4541 & 8.47 & 4.84 & 8.4 & 6.3 & 6.9 & $115,454,000,000$ & $30,433,058,782$ \\
\hline 2008 & 10.2815 & 4.3678 & 7.85 & 12.35 & 6.9 & 5.7 & $132,139,000,000$ & $35,713,730,182$ \\
\hline 2009 & -6.2894 & -2.963 & 5.59 & 2.75 & 7.2 & 6.9 & $102,588,000,000$ & $32,667,519,727$ \\
\hline 2010 & -0.2075 & 1.9932 & 6.09 & 2.44 & 6.8 & 10.3 & $106,549,000,000$ & $32,291,715,175$ \\
\hline 2011 & 1.5546 & 2.5706 & 5.79 & 4.22 & 7.1 & 11.4 & $116,592,000,000$ & $35,774,758,621$ \\
\hline 2012 & 1.09 & 0.612 & 3.33 & 2.95 & 6.8 & 12.4 & $108,407,000,000$ & $35,263,503,285$ \\
\hline 2013 & 3.9168 & 1.4281 & 3.99 & 0.89 & 7.1 & 13 & $116,807,000,000$ & $34,616,691,775$ \\
\hline 2014 & 3.4631 & 1.9064 & 1.07 & -1.42 & 6.8 & 11.5 & $123,016,000,000$ & $35,538,875,322$ \\
\hline 2015 & 4.4644 & 4.2807 & -0.59 & -0.1 & 6.9 & 9.2 & $109,961,000,000$ & $31,390,851,281$ \\
\hline
\end{tabular}

Source: [87,108-113].

Table A5. SPSS database for Romania and Bulgaria.

\begin{tabular}{ccccc}
\hline Year & ReR.Ro & ReR.Bu & Total.Migrants.Ro & Total.Migrants.Bu \\
\hline 1990 & & & 507,752 & 92,389 \\
1991 & & 531,328 & 98,193 \\
1992 & & 554,903 & 103,996 \\
1993 & & 578,479 & 109,800 \\
1994 & 0.483937 & & 602,054 & 115,603 \\
1995 & 0.396751 & & 625,630 & 121,407 \\
1996 & 0.795791 & 4.962437 & 654,024 & 128,919 \\
1997 & 0.709409 & 6.087534 & 682,418 & 136,432 \\
1998 & 2.177067 & 6.137477 & 710,811 & 143,944 \\
1999 & 4.271975 & 5.179633 & 739,205 & 151,457 \\
2000 & 4.277509 & 7.127812 & 767,599 & 158,969 \\
2001 & 5.241287 & 103.1572 & 962,317 & 196,480 \\
2002 & 6.580614 & 150.1757 & $1,157,035$ & 233,991 \\
2003 & 5.747572 & 221.0178 & $1,351,752$ & 271,502 \\
2004 & 6.106729 & 223.2475 & $1,546,470$ & 309,013 \\
2005 & 44.64341 & 210.5912 & $1,741,188$ & 346,524 \\
2006 & 54.75499 & 225.8165 & $1,902,441$ & 374,193 \\
2007 & 77.7802 & 224.4503 & $2,063,693$ & 401,861 \\
2008 & 82.88763 & 256.074 & $2,224,946$ & 429,530 \\
2009 & 33.5075 & 213.8232 & $2,386,198$ & 457,198 \\
2010 & 31.67831 & 180.2302 & $2,547,451$ & 484,867 \\
2011 & 34.45169 & 201.8405 & $2,606,870$ & 498,426 \\
2012 & 36.55486 & 198.3168 & $2,666,288$ & 511,986 \\
2013 & 176.0857 & 229.4472 & $2,844,544$ & 525,545 \\
2014 & 169.8355 & 233.2163 & $2,901,135$ & 540,731 \\
2015 & 155.7093 & 208.2393 & $2,957,726$ & 555,917 \\
\hline
\end{tabular}


Table A6. GINI coefficient.

\begin{tabular}{ccc}
\hline Year & GINI.Ro & GINI.Bu \\
\hline 1990 & 0.70 & 0.70 \\
1991 & 0.69 & 0.70 \\
1992 & 0.68 & 0.70 \\
1993 & 0.68 & 0.70 \\
1994 & 0.68 & 0.70 \\
1995 & 0.69 & 0.70 \\
1996 & 0.69 & 0.70 \\
1997 & 0.70 & 0.70 \\
1998 & 0.70 & 0.71 \\
1999 & 0.70 & 0.71 \\
2000 & 0.71 & 0.71 \\
2001 & 0.71 & 0.72 \\
2002 & 0.72 & 0.73 \\
2003 & 0.73 & 0.74 \\
2004 & 0.75 & 0.75 \\
2005 & 0.76 & 0.75 \\
2006 & 0.77 & 0.76 \\
2007 & 0.78 & 0.76 \\
2008 & 0.80 & 0.77 \\
2009 & 0.80 & 0.77 \\
2010 & 0.80 & 0.78 \\
2011 & 0.80 & 0.78 \\
2012 & 0.79 & 0.78 \\
2013 & 0.80 & 0.79 \\
2014 & 0.80 & 0.79 \\
2015 & 0.80 & 0.79 \\
2016 & & \\
\hline & Source: [87,95,111]. \\
\end{tabular}

\section{References}

1. Giddens, A. ALL: Bucharest, Romania. 2010. Available online: http://www.all.ro/media/attachment/file/ s/o/sociologie-anthony-giddens-pdf_2.pdf (accessed on 1 March 2018).

2. The World Bank. Migration and Remittances Data. 16 November 2017. Available online: http://www. worldbank.org/en/topic/migrationremittancesdiasporaissues/brief/migration-remittances-data (accessed on 7 January 2018).

3. The World Bank. Migration and Development Brief 27, Migration and Remittances. Recent Developments and Outlook, Special Topic: Global Compact on Migration, April 2017, World Bank Group, The Global Knowledge Partnership on Migration and Development (KNOMAD). Available online: http:/ / pubdocs.worldbank.org/en/ 992371492706371662/MigrationandDevelopmentBrief27.pdf (accessed on 7 January 2018).

4. Rosenzweig, R.M. Consequences of Migration for Developing Countries, United Nations Expert Group Meeting on International Migration and Development. 2005. Available online: http://web.pop.psu.edu/ projects/help_archive/help.pop.psu.edu/data-collections/new-immigrant-survey/P08_Rosenzweig.pdf (accessed on 17 March 2018).

5. Antman, M.F. The Impact of Migration on Family Left Behind, IZA Discussion Paper. 2012. Available online: http:/ /ftp.iza.org/dp6374.pdf (accessed on 15 March 2018).

6. Porumbescu, A. Defining the New Economics of labour Migration Theory Boundaries: A Sociological Level Analysis of International Migration. Rev. Stiinte Politice 2015, 45, 55-64.

7. Skeldon, R. Global Migration: Demographic Aspects and Its Relevance for Development, United Nations Department of Economic and Social Affairs Population Division Technical Paper. No. 6. 2013. Available online: http:/ /www.un.org/esa/population/migration/documents/EGM.Skeldon_17.12.2013.pdf (accessed on 17 March 2018). 
8. Potot, S. Transitioning Strategies of Economic Survival: Romanian Migration during the Transition Process. In A Continent Moving West? EU Enlargement and Labour Migration from Central and Eastern Europe; IMISCOE Research (International Migration, Integration and Social Cohesion in Europe); Black, R., Engbersen, G., Okólski, M., Panțîru, C., Eds.; Amsterdam University Press: Amsterdam, The Netherlands, 2010. Available online: http:/ / www.ssoar.info/ssoar/handle/document/27345 (accessed on 11 January 2018).

9. Markova, E.; Effects of Migration on Sending Countries. Lessons from Bulgaria, GreeSE Paper, No. 35, Hellenic Observatory, Papers on Greece and Southeast Europe. 2010. Available online: http:/ / eprints.lse.ac. uk/28438/1/GreeSE_No35.pdf (accessed on 23 January 2018).

10. Aggarwal, R.; Demirgúç-Kunt, A.; Soledad, M.; Peria, M. Do remittances promote financial development? J. Dev. Econ. 2011, 96, 255-264. [CrossRef]

11. Alcaraz, C.; Chiquiar, D.; Salcedo, A. Remittances, schooling and child labor in Mexico. J. Dev. Econ. 2012, 97, 156-165. [CrossRef]

12. Amnedo-Dorantes, C.; Mazzolary, F. Remittances to Latin America from migrants in the United States: Assessing the impact of amnesty programs. J. Dev. Econ. 2010, 91, 323-335. [CrossRef]

13. Barham, B.; Boucher, S. Migration, remittances and inequality: Estimating the net effects of migration on income distribution. J. Dev. Econ. 1998, 55, 307-331. [CrossRef]

14. Djajić, S. International Migration, Remittances and Welfare in a Dependent Economy. J. Dev. Econ. 1986, 229-234. [CrossRef]

15. Strielkowski, W.; Šperková, L.; Jacek, B. Migration and Remittances Nexus: Economic Implications and Analysis. Amfiteatru Econ. 2017, 19, 771-789.

16. Dustmann, C.; Mesters, J. Remittances and temporary migration. J. Dev. Econ. 2010, 92, 62-70. [CrossRef]

17. Martin, P.L. Migration and development: Toward sustainable solutions. Discuss. Paper 2004, 153, 3-25.

18. Chirila, V.; Chirila, C. The Analysis of Romania's External Migration and of the Causality between Remittances and Romania's Economic Growth. Amfiteatru Econ. 2017, 19, 696-710.

19. Giuliano, P.; Ruiz-Arranz, M. Remittances, financial development and growth. J. Dev. Econ. 2009, 90, 144-152. [CrossRef]

20. Dilip, R. Migration and Remittances. Recent Developments and Outlook, Migration and Development Brief 26. International Bank for Reconstruction and Development; The World Bank: Washington, DC, USA, 2016. Available online: http:/ / pubdocs.worldbank.org/en/661301460400427908/MigrationandDevelopmentBrief26. pdf (accessed on 19 March 2018).

21. Giuliano, P.; Ruiz-Arranz, M. Remittances, Financial Development and Growth; IMF Working Paper 2005, 05/234; International Monetary Fund: Washington, DC, USA. Available online: https:/ / www.imf.org/external/ pubs/ft/wp/2005/wp05234.pdf (accessed on 17 March 2018).

22. Simionescu, L.; Dumitrescu, D. Migrants Remittances Influence on Fiscal Sustainability in Dependent Economies. Amfiteatru Econ. 2017, 19, 640-653.

23. Conrad, H. Remittances and the migration-development nexus-Challenges for the sustainable governance of migration. Ecol. Econ. 2006, 59, 231-236. [CrossRef]

24. Daianu, D.; Voinea, L.; Tolici, M. Balance of Payments Financing in Romania. The Role of Remittances, RCEP/WP; Romanian Centre for Economic: Romanian, 2001. Available online: http:/ /www.sar.org.ro/wp-content/ uploads /2012/01/Balance-of-Payments-Financing-in-Romania-The-Role-of-Remittances.pdf (accessed on 18 March 2018).

25. Haller, A. Globalisation, Multinational Companies and Emerging Markets. Ecoforum J. 2016, 5. Available online: http:/ / www.ecoforumjournal.ro/index.php/eco/article/viewFile/277/183 (accessed on 17 March 2018).

26. Haller, A. Concepts of Economic Growth and Development. Challenges of Crisis and of Knowledge. ETC J. 2012, 15, 66.

27. Ravenstein, E.G. The Law of Migration. J. Stat. Soc. Lond. 1885, 48, 167-235. [CrossRef]

28. Rogers, A. Demographic Modelling of the Geography of Migration and Population: A Multiregional Perspective. Population Program POP2007-02. 2006. Available online: https://www.colorado.edu/ibs/ pubs/pop/pop2007-0002.pdf (accessed on 15 January 2018).

29. Zelinsky, W. The Hypothesis of Mobility Transition. American Geographical Society. Geogr. Rev. 1971, 61, 221-249. [CrossRef] 
30. Wright, R.; Mark, E. Perspectives on Migration Theory: Geography; Springer: Berlin, Germany, 2009. Available online: www.springer.com/cda/content/document/cda.../9789401772815-c2.pdf?SGWID (accessed on 10 December 2017).

31. King, R. Geography and Migration Studies: Retrospect and Prospect. Popul. Space Place 2012, 18, $134-153$. [CrossRef]

32. Piore, M.J. The Shifting Grounds for Immigration, Annals of the American Academy of Political and Social Science. Available online: http://www.migrationpolicycentre.eu/docs/SummerSchool2013/readings/ Kaczmarczyk_Reading\%207.pdf (accessed on 1 February 2018).

33. Gordon, H.H. The Economic Consequences of International Migration of Labor. Ann. Rev. Econ. 2009, 1, 179-207.

34. Kurekova, L. Theories of migration: Conceptual Review and Empirical Testing in the Context of the EU East-West Flows. In Proceedings of the Interdisciplinary Conference on Migration. Economic Change, Social Challenge, London, UK, 6-9 April 2011. Available online: http:/ / cream.conference-services.net/resources / 952/2371/pdf/mecsc2011_0139_paper.pdf (accessed on 2 January 2018).

35. Collins, R.; Wallerstein, I.; Mann, M.; Derluguian, R.; Callhoun, C. Are Capitalismul un Viitor. 2015. Available online: https: / / carturesti.ro/ carte/are-capitalismul-un-viitor-282019 (accessed on 17 December 2017).

36. Galbraith, J. Despre Inegalitate. Available online: https://carturesti.ro/carte/are-capitalismul-un-viitor282019 (accessed on 17 December 2017).

37. Stark, O.; Bloom, D. The New Economics of Labor Migration. Am. Econ. Rev. 1987, 75, 173-178.

38. Gieseck, A. The Migration of Labor by Oded Stark. 1995. Available online: https:/ / search-proquest-com. proxy.bibliotheques.uqam.ca:2443/docview/213218052?accountid=14719 (accessed on 31 January 2018).

39. McDowell, C.; De Haan, A. Migration and Sustainable Livelihoods: A Critical Review of the Literature, IDS Working Paper 65. 1997. Available online: https:/ /www.ids.ac.uk/files/dmfile/Wp65.pdf (accessed on 17 January 2018).

40. Boswell, C. Addressing the Causes of Migratory and Refugee Movements: The Role of the European Union. Institute for Peace Research and Security Policy. University of Hamburg-Germany; Working Paper No. 73; UNHCR-The UN Refugee Agency: Geneva, Switzerland, 2002. Available online: http://www.refworld.org/docid/ 4ff3f6272.html (accessed on 20 October 2017).

41. Boswell, C. Combining Economics and Sociology in Migration Theory. J. Ethn. Migr. Stud. 2008, 34, 549-566. [CrossRef]

42. O'Reilly, K. International Migration and Social Theory; Palgrave Macmillan: Basingstoke, UK, 2012. Available online: https:/ / dspace.lboro.ac.uk/dspace-jspui/bitstream/2134/15688/3/International\%20Migration\% 20and\%20Social\%20Theory\%20v3.pdf (accessed on 17 January 2018).

43. Kerr, S.P.; Kerr, R.W. Economic Impacts of Immigration: A Survey. NBER Working Paper, No. 16736. 2011. Available online: http:/ / www.nber.org/papers/w16736.pdf (accessed on 12 December 2017).

44. Binnie, K.A. Psychology of the Refugee, the Immigrant and their Children; Department of Psychology, University of Lund: Lund, Sweden, 2000. Available online: http:/ / www.andrasprak.su.se/polopoly_fs/1.95996.1343111262! /menu/standard/file/PSYCHOLOGY\%20OF\%20THE\%20REFUGEE.pdf (accessed on 2 January 2018).

45. Berry, J.W. A Psychology of Immigration. J. Soc. Issues 2001, 57, 615-631. [CrossRef]

46. Esses, V.; Deaux, K.; Lalonde, R.; Brown, R. Psychological Perspectives on Immigration. J. Soc. 2010, 66, 635-647. [CrossRef]

47. Gurieva, S.; Kinunen, T. Social-Psychological Model of the "Migration Circle": Potential Emigrants, Migrants, Remigrants. Open J. Soc. Sci. 2014, 2, 174-182. [CrossRef]

48. Brown, S.C. The Educational Psychological and Social Impact of Discrimination on the Immigrant Child; Migration Policy Institute: Washington, DC, USA, 2015. Available online: https:/ /www.migrationpolicy.org/research/ educational-psychological-and-social-impact-discrimination-immigrant-child (accessed on 8 January 2018).

49. Colson, E. Forced Migration and the Anthropological Response. J. Refug. Stud. 2003, 16, 1-8. [CrossRef]

50. Fitzgerald, D. Towards a Theoretical Ethnography of Migration. Qual. Soc. 2006, 29, 1-24. [CrossRef]

51. Horevitz, E. Understanding the Anthropology of Immigration and Migration. J. Hum. Behav. Soc. Environ. 2009, 19, 745-785. [CrossRef]

52. Salaza, N. Towards an Anthropology of Cultural Mobilities. J. Migr. Cult. 2010, 1, 53-68. [CrossRef]

53. Kempny, M. Rethinking Native Anthropology: Migration and Auto-Ethnography in the Post-Accession Europe. Int. Rev. Soc. Res. 2012, 2, 39-52. [CrossRef] 
54. Budnik, K. Temporary Migration in Theories of International Mobility of Labour. National Bank of Poland. Working Paper No. 89. 2011. Available online: https://www.nbp.pl/publikacje/materialy_i_studia/89_en. pdf (accessed on 17 December 2017).

55. Solow, M.R. A Contribution to the Theory of Economic Growth. Q. J. Econ. 1956, 70, 65-94. [CrossRef]

56. Kalinowska, B.; Knapińska, M. Review of Chosen Migration Theories. Available online: http://www. mikroekonomia.net/system/publication_files/145/original/3.pdf?1314883815 (accessed on 7 January 2018).

57. Borjas, G. The Economics of Immigration. J. Econ. Lit. 1994, XXXII, 1667-1717.

58. Borjas, G. Immigration and the American Worker. A Review of the Academic Literature; Center for Immigration Studies: Washington, DC, USA, 2013. Available online: https://sites.hks.harvard.edu/fs/gborjas/ publications/popular/CIS2013.pdf (accessed on 2 January 2018).

59. Orefice, G. Skilled Migration and Economic Performance: Evidence from OECD Countries. Discussion Paper 2010015. 2010. Available online: http://sites.uclouvain.be/econ/DP/IRES/2010015.pdf (accessed on 20 October 2017).

60. De Hein, H. The Determinants of International Migration. In Conceptualising Policy, Origin and Destination Effects; IMI Working Papers Series; International Migration Institute-University of Oxford: Oxford, UK, 2011.

61. De Hein, H. The International Dynamics of Migration Processes: A Theoretical Inquiry. J. Ethic Migr. Stud. 2010, 36, 1587-1617.

62. De Hein, H. International Migration, Remittances and Development: Myths and Facts. Third World Q. 2005, $29,1269-1284$.

63. Coyle, D. Guvernarea Economiei Mondiale; Antet: Bucharest, Romania, 2000.

64. Lee, S.E. A Theory of Migration. Demography 1966, 3, 47-57. [CrossRef]

65. Crawford, T. Beliefs about Birth Control: A Consistency Theory Analysis. Represent. Res. Soc. Psychol. 1973, 4, 53-65. [PubMed]

66. Hagen-Zanker, J. Why do People Migrate? A Review of the Theoretical Literature; Working Paper MGS0G/ 2008/WP002; Maastricht University: Maastricht, The Netherlands, 2008.

67. Wolpert, J. Behavioural Aspects of the Decision to Migrate. Pap. Reg. Sci. Assoc. 1965, 15, 159-169. [CrossRef]

68. Drèze, J.; Stern, N. The Theory of Cost-Benefit Analysis. 1987. Available online: http:/ / personal.lse.ac.uk/ sternn/040NHS.pdf (accessed on 7 January 2018).

69. Squartini, T.; Garlaschelli, D. Jan Tinbergen's Legacy for Economic Networks: From Gravity Model to Quantum Statistics. 2013. Available online: https://arxiv.org/pdf/1304.3252.pdf (accessed on 27 December 2017).

70. Sinha, B.R. Human Migration: Concepts and Approaches. 2005. Available online: http://www.mtafki.hu/ konyvtar/kiadv/FE2005/FE20053-4_403-414.pdf (accessed on 31 January 2018).

71. Bulow, J.; Summers, L. A Theory of Dual Labor Markets with Application to Industrial Policy, Discrimination and Keynesian Unemployment. NBER Working Paper. 1666. 1985, pp. 376-415. Available online: https: / / core.ac.uk/download/pdf/6690394.pdf (accessed on 17 December 2017).

72. Myrdal, G. Economic Theory and Underdeveloped Regions. 1957. Available online: https://www. scribd.com/document/79781755/G-Myrdal-Economic-Theory-and-Underdeveloped-Regions (accessed on 4 January 2018).

73. Katz, N.; Lazer, D.; Arrow, H.; Contractor, N. Network Theory and Small Groups, Small Group Research; SAGE Publications: Thousand Oaks, CA, USA, 2004; Volume 35, pp. 307-332.

74. Ravenstein, E.G. The Law of Migration. 1889. Available online: https://www.jstor.org/stable/2979333?seq= 1\#page_scan_tab_contents (accessed on 25 February 2018).

75. Dick, A. Country Analysis: A Framework to Evaluate the National Business Environment; Harvard Business Review: Cambridge, MA, USA, 1997; ISBN 9-797-092. Available online: http://hbr.org/product/countryanalysis-a-framework-to-identify-and-evalu/an/797092-PDF-ENG (accessed on 19 March 2018).

76. Lubambu, K.; Manyonga, K. The Impact of Remittances on Developing Countries, Directorate-General for External Policies of the European Union. 2013. Available online: http://www.europarl.europa.eu/ meetdocs/2009_2014/documents/deve/dv/remittances_study_/remittances_study_en.pdf (accessed on 17 March 2018).

77. Andrén, D.; Roman, M. Should I Stay or Should I Go? Romanian Migrants during Transition and Enlargements. IZA, Discussion Paper No. 8690. 2014. Available online: http://ftp.iza.org/dp8690.pdf (accessed on 17 January 2018). 
78. Hărău, C. Migration and Remittances-Case Study on Romania. Annals Fac. Eng. Hunedoara-Int. J. Eng. 2011, 9, 123-129, Tome IX, Extra Fascicule.

79. De Sousa, J.; Duval, L. Geographic distance and remittances in Romania: Out of sight, out of mind? Int. Econ. 2015, 1, 81-97. [CrossRef]

80. Silaşi, G.; Simina, O.L. Romania and the New Economy of Migration: Costs, Decision, Networks, Development; SISEC Discussion Papers; 2008; Volume 7. Available online: http://aei.pitt.edu/14049/ 1/SDP_7-2-2008_Silasi_Simina.pdf (accessed on 18 March 2018).

81. Markova, E. Optimising Migration Effects: A Perspective from Bulgaria. In A Continent Moving West? EU Enlargement and Labour Migration from Central and Eastern Europe; Black, R., Engbersen, G., Okólski, M., Panțîru, C., Eds.; IMISCOE Research (International Migration, Integration and Social Cohesion in Europe); Amsterdam University Press: Amsterdam, The Netherlands, 2010. Available online: http:/ /www.ssoar.info/ ssoar/handle/document/27345 (accessed on 23 January 2018).

82. Mintchev, V.; Boshnakov, V. Return Migration and Development Prospects after EU Integration: Empirical Evidence from Bulgaria. In A Continent Moving West? EU Enlargement and Labour Migration from Central and Eastern Europe; Black, R., Engbersen, G., Okólski, M., Panțîru, C., Eds.; IMISCOE Research (International Migration, Integration and Social Cohesion in Europe); Amsterdam University Press: Amsterdam, The Netherlands, 2010. Available online: http:/ /www.ssoar.info/ssoar/handle/document/ 27345 (accessed on 21 January 2018).

83. Mansoor, A.; Quillin, B. Migration and Remittances. Eastern Europe and the Former Soviet Union; The World Bank: Washington, DC, USA, 2007; ISBN 978-0-8213-6233-41. Available online: http:/ / siteresources.worldbank. org/INTECA/Resources/257896-1167856389505/Migration_FullReport.pdf (accessed on 16 March 2018).

84. Unicef, Romania, Migration Profiles, Part I. Global Legal Instruments Related to International Migration. Available online: https:/ / esa.un.org/miggmgprofiles/indicators/files/Romania.pdf (accessed on 27 January 2018).

85. Unicef, Bulgaria, Migration Profiles, Part I. Global Legal Instruments Related to International Migration. Available online: https:/ / esa.un.org/miggmgprofiles/indicators/files/Bulgaria.pdf (accessed on 27 January 2018).

86. United Nations, Department of Economic and Social Affairs, Population Division. Trends in International Migrant Stock: Migrants by Destination and Origin (United Nations database, POP/DB/MIG/Stock/Rev.2015). 2015. Available online: www.un.org/en/.../desa/population/migration/.../UN_MigrantStockTotal_2015.xlsx (accessed on 12 December 2017).

87. Eurostat, Coefficient de Gini du Revenudis Ponibleéquivalent-Enquête EU-SILC. Available online: http: / / appsso.eurostat.ec.europa.eu/nui/show.do?dataset=ilc_di12\&lang=fr (accessed on 11 December 2017).

88. Glennie, A.; Pennington, J. In Transition: Romanian and Bulgarian Migration to the UK; Institute for Public Research: London, UK, 2013. Available online: https:/ /www.barrowcadbury.org.uk/wp-content/uploads / 2013/12/IPPR-In-Transition-2013.pdf (accessed on 18 December 2017).

89. Kausar, R. Identifying Social and Economic Push and Pull Factors for Migration to the UK by Bulgarian and Romanian Nationals, Department for Communities and Local Government, London. 2011. Available online: http: / webarchive.nationalarchives.gov.uk/20120919152848/http:/ / www.communities.gov.uk/ documents/corporate/pdf/19971601.pdf (accessed on 2 December 2017).

90. Yüksel, S.; Mukhtarov, S.; Mahmudlu, C.; Mikayilov, J.I.; Iskandarov, A. Measuring International Migration in Azerbaijan. Sustainability 2018, 10, 132. [CrossRef]

91. The World Bank. World Bank National Accounts Data and OECD National Accounts Data Files. GDP per Capita Growth (Annual \%). Available online: https:/ / data.worldbank.org/indicator/NY.GDP.PCAP.KD.ZG (accessed on 17 March 2018).

92. International Monetary Fund, International Financial Statistics and Data Files. Available online: http: / / www.imf.org/en/Data (accessed on 17 March 2018).

93. International Labor Organization. Available online: http://www.ilo.org/public/english/bureau/stat/res/ index.htm (accessed on 17 March 2018).

94. The World Bank, Data Bank. World Development Indicators. Popular Indicators. Available online: http:/ / databank.worldbank.org/data/reports.aspx?Code=SI.POV.NAHC\&id=1ff4a498\&report_name= Popular-Indicators\&populartype=series\&ispopular=y\# (accessed on 17 March 2018).

95. GINI Index, World Bank Estimate. Available online: https:// data.worldbank.org/indicator/SI.POV.GINI (accessed on 9 January 2018). 
96. The World Bank, Data Bank, World Development Indicators. Available online: http:/ / databank.worldbank. org $/$ data $/$ reports.aspx?Code=SI.POV.NAHC\&id=1ff4a498\&report_name=Popular-Indicators\& populartype=series\&ispopular $=y \#$ (accessed on 17 March 2018).

97. The World Bank, Personal Remittances, Received, Data are in Current U.S. Dollars. Available online: https: / / data.worldbank.org/indicator/BX.TRF.PWKR.CD.DT (accessed on 17 March 2018).

98. Malhotra, N.; Décaudin, J.M.; Bouguerra, A.; Bories, D. Études Marketing avec SPSS, 6th ed.; Pearson Education: London, UK, 2011; 709p.

99. United Nations, Department of Economic and Social Affairs, Population Division. International Migration Report 2017: Highlights (ST/ESA/SER.A/404). 2017. Available online: http:/ / www.un.org/en/development/ desa/population/migration/publications/migrationreport/docs/MigrationReport2017_Highlights.pdf (accessed on 11 February 2018).

100. Haller, A.P.; Alter-Globalism and Development in Migration Conditions. The Case of an East European Country. Cross Cult. Manag. J. 2017, XIX, 95-103. Available online: http:/ / seaopenresearch.eu/Journals/ articles/CMJ2017_I2_2.pdf (accessed on 11 February 2018).

101. Docquier, F. The brain drain from developing countries. IZA World Labor 2014. [CrossRef]

102. Dustmann, C.; Glitz, A. Migration and Education. Available online: http:/ /www.norface-migration.org/ publ_uploads/NDP_11_11.pdf (accessed on 18 March 2018).

103. Docquier, F.; Rapoport, H. Globalization, Brain Drain and Development. J. Econ. Lit. 2011, 50, 681-730. [CrossRef]

104. Dodani, S.; LaPorte, R.E. Brain drain from developing countries: How can brain drain be converted into wisdom gain? J. R. Soc. Med. 2005, 98, 487-491. [CrossRef] [PubMed]

105. Rizvi, F. Rethinking Brain Drain, in the Era of Globalisation. Asia Pac. J. Educ. 2005, 25, 175-192. [CrossRef]

106. Black, R.; Engbersen, G.; Okólski, M.; Panțîru, C. (Eds.) A Continent Moving West? EU Enlargement and Labour Migration from Central and Eastern Europe; IMISCOE Research (International Migration, Integration and Social Cohesion in Europe); Amsterdam University Press: Amsterdam, The Netherlands. Available online: https:/ /www.ssoar.info/ssoar/bitstream/handle/document/27345/ssoar-2010-black_ et_al-a_continent_moving_west_eu.pdf?sequence=1 (accessed on 23 January 2018).

107. Engbersen, G.; Snel, E.; Boom, J. A Van Full of Poles: Liquid Migration from Central and Eastern Europe. In A Continent Moving West? EU Enlargement and Labour Migration from Central and Eastern Europe; Black, R., Engbersen, G., Okólski, M., Panțîru, C., Eds.; IMISCOE Research (International Migration, Integration and Social Cohesion in Europe); Amsterdam University Press: Amsterdam, The Netherlands, 2010. Available online: http:/ / www.ssoar.info/ssoar/handle/document/27345 (accessed on 3 January 2018).

108. The World Bank. Foreign Direct Investment, Net Inflows (BoP, Current US\$). Available online: https: / / data.worldbank.org/indicator/BX.KLT.DINV.CD.WD (accessed on 7 January 2018).

109. The World Bank. NET Primary Income (BoP, Current US\$). Available online: https:/ / data.worldbank.org/ indicator/BN.GSR.FCTY.CD (accessed on 7 January 2018).

110. The World Bank. Expense (Current LCU). Available online: https://data.worldbank.org/indicator/GC. XPN.TOTL.CN (accessed on 7 January 2018).

111. The World Bank. Imports of Goods, Services and Primary Income (BoP, Current US\$). Available online: https:/ / data.worldbank.org/indicator/BM.GSR.TOTL.CD (accessed on 7 January 2018).

112. The World Bank. Foreign Direct Investment, Net Outflows (BoP, Current US\$). Available online: https: / / data.worldbank.org/indicator/BM.KLT.DINV.CD.WD (accessed on 7 January 2018).

113. The World Bank. Exports of Goods, Services and Primary Income (BoP, Current US\$). Available online: https:/ / data.worldbank.org/indicator/BX.GSR.TOTL.CD (accessed on 7 January 2018).

(C) 2018 by the authors. Licensee MDPI, Basel, Switzerland. This article is an open access article distributed under the terms and conditions of the Creative Commons Attribution (CC BY) license (http:/ / creativecommons.org/licenses/by/4.0/). 